\title{
Water-Quality Assessment of the Potomac River Basin: Occurrence of Pesticides in the Great Valley Carbonate Subunit
}

Water-Resources Investigations Report 98-4054

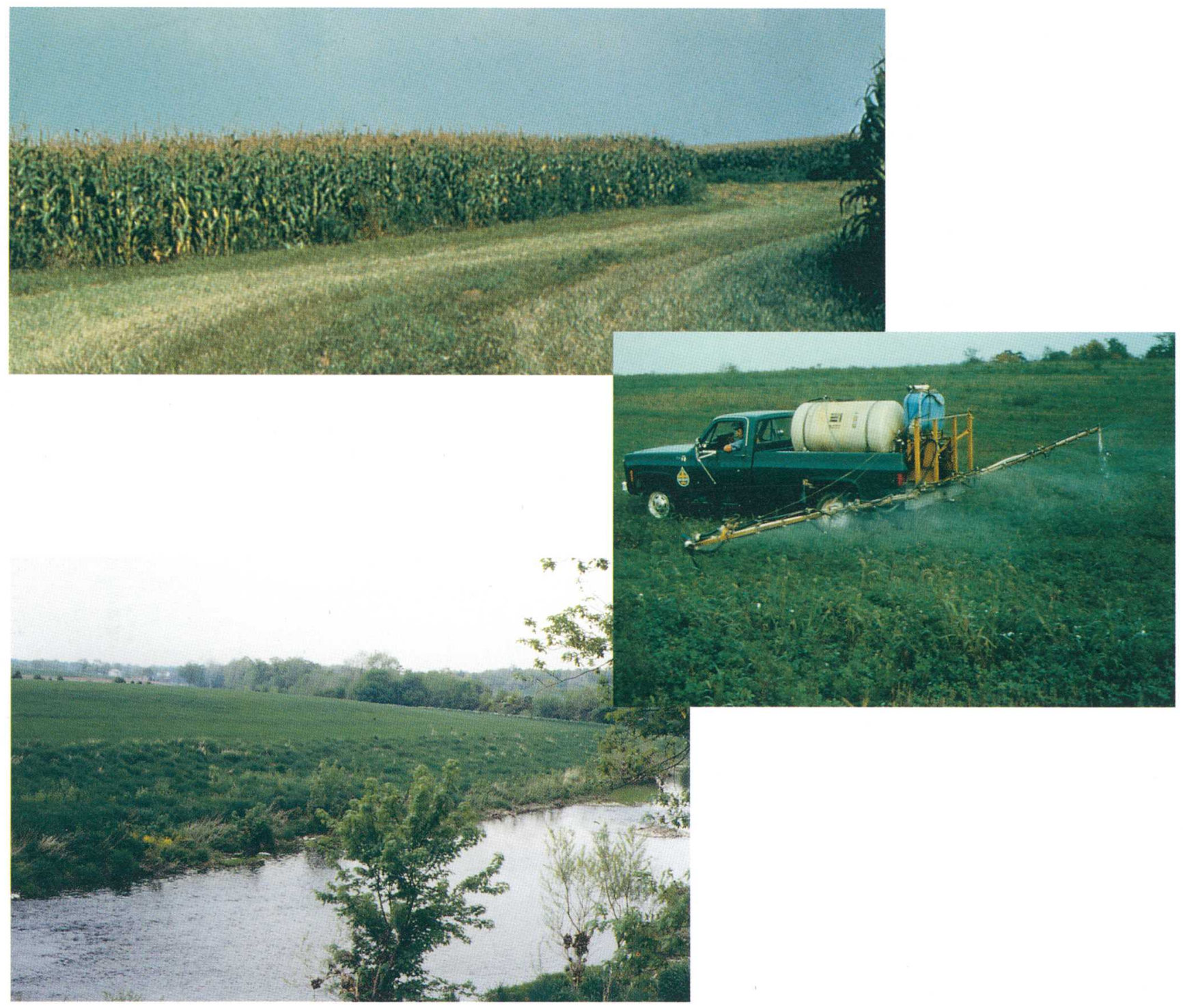




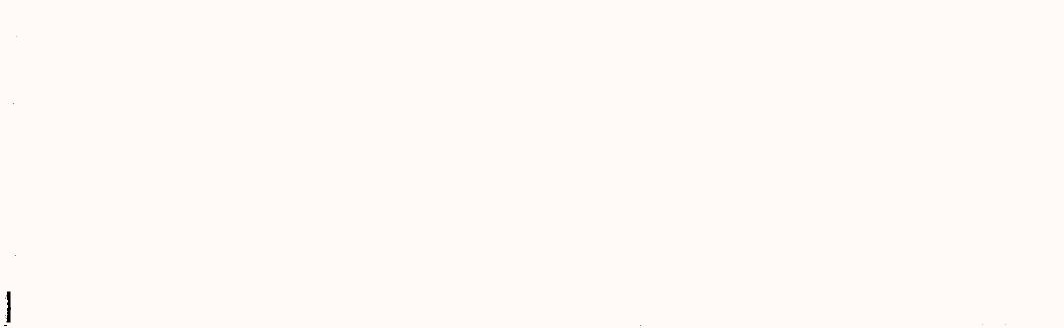




\section{Water-Quality Assessment of the Potomac River Basin: Occurrence of Pesticides in the Great Valley Carbonate Subunit}

By Matthew J. Ferrari and Janet M. Denis

U.S. GEOLOGICAL SURVEY

Water-Resources Investigations Report 98-4054 


\section{U.S. DEPARTMENT OF THE INTERIOR BRUCE BABBITT, Secretary}

U.S. GEOLOGICAL SURVEY

Charles G. Groat, Director

The use of trade, product, or firm names in this report is for descriptive purposes only and does not imply endorsement by the U.S. Geological Survey.

For additional information write to:

District Chief

U.S. Geological Survey 8987 Yellow Brick Road

Baltimore, MD 21237
Copies of this report can be purchased from:

U.S. Geological Survey

Branch of Information Services

Box 25286

Denver, CO 80225-0286 


\section{FOREWORD}

The mission of the U.S. Geological Survey (USGS) is to assess the quantity and quality of the earth resources of the Nation and to provide information that will assist resource managers and policymakers at Federal, State, and local levels in making sound decisions. Assessment of water-quality conditions and trends is an important part of this overall mission.

One of the greatest challenges faced by waterresources scientists is acquiring reliable information that will guide the use and protection of the Nation's water resources. That challenge is being addressed by Federal, State, interstate, and local water-resource agencies and by many academic institutions. These organizations are collecting water-quality data for a host of purposes that include: compliance with permits and water-supply standards; development of remediation plans for specific contamination problems; operational decisions on industrial, wastewater, or watersupply facilities; and research on factors that affect water quality. An additional need for water-quality information is to provide a basis on which regionaland national-level policy decisions can be based. Wise decisions must be based on sound information. As a society we need to know whether certain types of water-quality problems are isolated or ubiquitous, whether there are significant differences in conditions among regions, whether the conditions are changing over time, and why these conditions change from place to place and over time. The information can be used to help determine the efficacy of existing waterquality policies and to help analysts determine the need for and likely consequences of new policies.

To address these needs, the U.S. Congress appropriated funds in 1986 for the USGS to begin a pilot program in seven project areas to develop and refine the National Water-Quality Assessment (NAWQA) Program. In 1991, the USGS began full implementation of the program. The NAWQA Program builds upon an existing base of water-quality studies of the USGS, as well as those of other Federal, State, and local agencies. The objectives of the NAWQA Program are to:

- Describe current water-quality conditions for a large part of the Nation's freshwater streams, rivers, and aquifers.
- Describe how water quality is changing over time.

- Improve understanding of the primary natural and human factors that affect water-quality conditions.

This information will help support the development and evaluation of management, regulatory, and monitoring decisions by other Federal, State, and local agencies to protect, use, and enhance water resources.

The goals of the NAWQA Program are being achieved through ongoing and proposed investigations of 60 of the Nation's most important river basins and aquifer systems, which are referred to as study units. These study units are distributed throughout the Nation and cover a diversity of hydrogeologic settings. More than two-thirds of the Nation's freshwater use occurs within the 60 study units and more than twothirds of the people served by public water-supply systems live within their boundaries.

National synthesis of data analysis, based on aggregation of comparable information obtained from the study units, is a major component of the program. This effort focuses on selected water-quality topics using nationally consistent information. Comparative studies will explain differences and similarities in observed water-quality conditions among study areas and will identify changes and trends and their causes. The first topics addressed by the national synthesis are pesticides, nutrients, volatile organic compounds, and aquatic biology. Discussions on these and other waterquality topics will be published in periodic summaries of the quality of the Nation's ground and surface water as the information becomes available.

This report is an element of the comprehensive body of information developed as part of the NAWQA Program. The program depends heavily on the advice, cooperation, and information from many Federal, State, interstate, Tribal, and local agencies and the public. The assistance and suggestions of all are greatly appreciated.

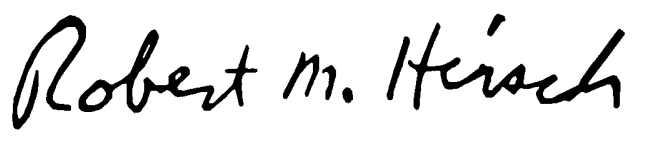

Robert M. Hirsch Chief Hydrologist 
$$
\text { . }
$$ 


\section{CONTENTS}

Foreword

Abstract.

Introduction

Purpose and scope

The National Water-Quality Assessment Program....

The Great Valley Carbonate subunit....

Pesticide use and effects

Acknowledgments

Methods of study

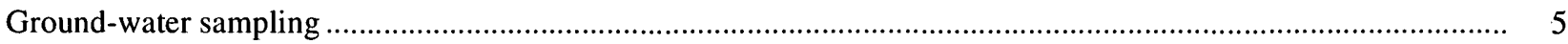

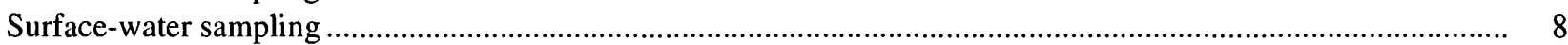

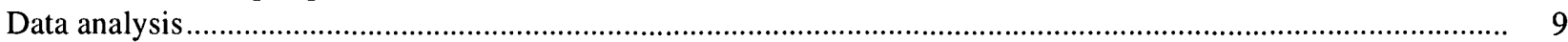

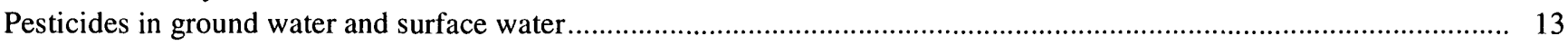

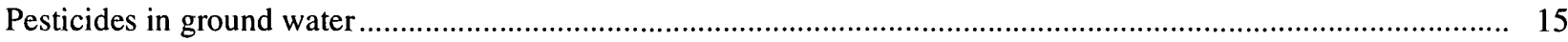

Small-scale variability in pesticide occurrence and concentrations in ground water.................................. 16

Temporal variability in pesticide occurrence and concentrations in ground water ................................... 17

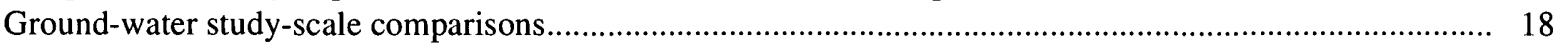

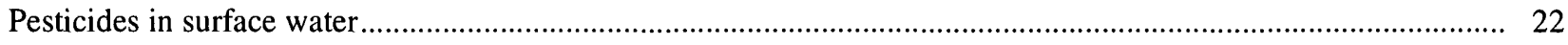

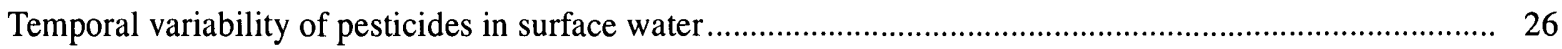

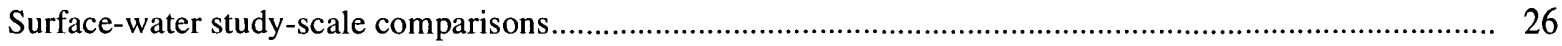

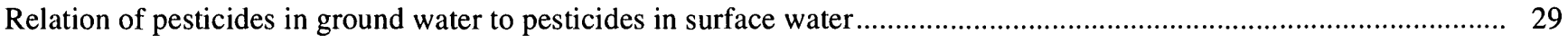

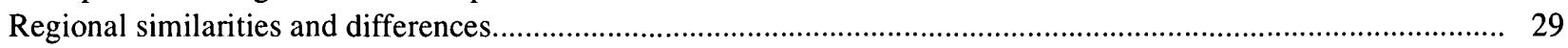

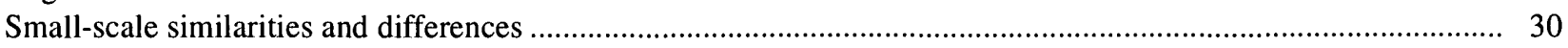

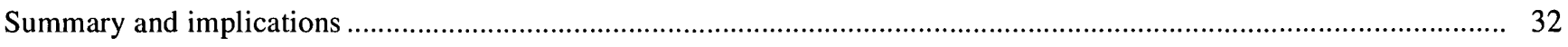

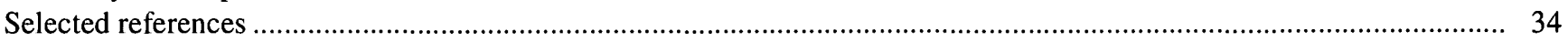

\section{Figures}

1-8. Maps showing:

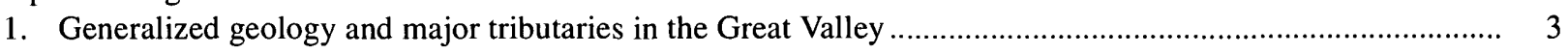

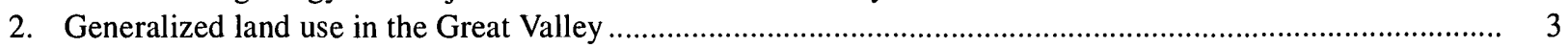

3. Ground-water sampling locations in the Great Valley Carbonate subunit................................................ 5

4. Locations of the sampled wells, surface-water gaging station, general land use,

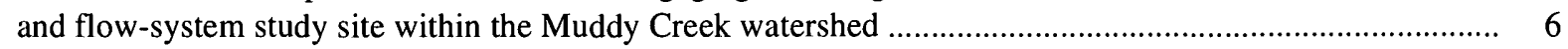

5. Well network, topography, and land use at the Muddy Creek flow-system study site ............................... 7

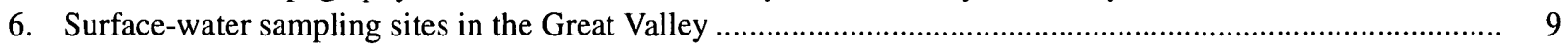

7. Number of pesticide compounds detected at each ground-water subunit survey well in the Great Valley Carbonate subunit

8. Distribution of atrazine concentrations in ground water from the 1993 Great Valley Carbonate subunit survey and the percentage of land used for crop production in each county....

9. Boxplots showing distributions of pesticide compound concentrations in ground-water samples from the 1993 Great Valley Carbonate subunit survey by geographic region..

10. Graphs showing relation between measured pesticide concentrations in ground-water samples and estimated amounts applied within half a mile of the wells in the Great Valley Carbonate subunit.

11. Boxplots showing distributions of concentrations of selected pesticide compounds in ground-water samples from the Muddy Creek flow-system study site...

12. Graphs showing comparison of ground-water-level elevations and concentrations of selected pesticide compounds from a well pair at the Muddy Creek flow-system study site 
13. Boxplots showing distributions of concentrations of selected pesticide compounds in synoptic ground-water samples from the Muddy Creek flow-system study site.

14. Boxplots showing distributions of concentrations of selected pesticide compounds in ground-water samples at three different study scales in the Great Valley Carbonate subunit....

15. Map showing number of pesticide compounds detected at each surface-water subunit synoptic survey sampling location in the Great Valley

16. Map showing distribution of atrazine concentrations in surface water from the 1993 Great Valley Carbonate subunit synoptic survey and the percentage of land used for crop production in each county.

17. Boxplots showing distributions of concentrations of pesticide compounds in surface water from the 1993 Great Valley Carbonate subunit synoptic survey by geographic region .....

18. Graphs showing relation between measured pesticide concentrations in stream samples and estimated amounts applied per square mile within the contributing basins, Great Valley Carbonate subunit .....

19. Graphs showing streamflow and pesticide concentrations for two fixed sites in the Great Valley

20. Boxplots showing distributions of concentrations of selected pesticide compounds at two fixed sites in the Great Valley....

21. Boxplots showing pesticide concentrations in ground water and surface water in the Great Valley Carbonate subunit, 1993 .

22. Map showing concentrations of simazine in ground water and surface water in the Great Valley Carbonate subunit, 1993.

23. Graphs showing comparison of streamflow and ground-water-level elevations to atrazine concentrations between the Muddy Creek fixed site and one of the ground-water flow-system well pairs......

Tables

1. The 20 most widely used agricultural pesticides in the Great Valley.....

2. Ground-water sampling networks and design for the Great Valley Carbonate subunit, 1993-1995 ................... 5

3. Surface-water sampling networks and design for the Great Valley Carbonate subunit, 1993-1995 .................. 8

4. Results of analyses of quality-control samples, ground water and surface water, in the Great Valley Carbonate subunit, 1993 to 1995 .....

5. County agricultural land-use statistics for the Great Valley

6. County agricultural pesticide-use estimates for the Great Valley.....

7. Examples of estimated atrazine applications within half a mile of four wells in the Great Valley Carbonate subunit

8. Pesticides and degradation products for which water samples from the Great Valley Carbonate subunit were analyzed.

9. Occurrence of pesticides and related compounds in water samples from the Great Valley ....

10. Correlation of concentrations of pesticides in ground water to land-use percentages within half a mile of the wells in the Great Valley Carbonate subunit ....

11. Selected physical characteristics and concentrations of selected pesticides detected at 25 surface-water sites under base-flow conditions in the Great Valley Carbonate subunit, September 1993.

12. Correlation of concentrations of pesticides in surface water to land-use percentages in contributing watersheds in the Great Valley Carbonate subunit 
CONVERSION FACTORS, VERTICAL DATUM, AND ABBREVIATIONS

\begin{tabular}{|c|c|c|}
\hline Multiply & By & To obtain \\
\hline \multicolumn{3}{|c|}{ Length } \\
\hline inch (in.) & 2.54 & centimeter \\
\hline foot $(\mathrm{ft})$ & 0.3048 & meter \\
\hline mile (mi) & 1.609 & kilometer \\
\hline \multicolumn{3}{|c|}{ Area } \\
\hline acre & 4,047 & square meter \\
\hline acre & 0.4047 & hectare \\
\hline square mile $\left(\mathrm{mi}^{2}\right)$ & 259.0 & hectare \\
\hline square mile $\left(\mathrm{mi}^{2}\right)$ & 2.590 & square kilometer \\
\hline \multicolumn{3}{|c|}{ Flow rate } \\
\hline \multirow[t]{2}{*}{ cubic foot per second $\left(\mathrm{ft}^{3} / \mathrm{s}\right)$} & $\overline{0.02832}$ & cubic meter per second \\
\hline \multirow{2}{*}{\multicolumn{3}{|c|}{ pound, avoirdupois (lb) }} \\
\hline & & \\
\hline \multicolumn{3}{|c|}{ Application rate } \\
\hline pound per acre per year $[(\mathrm{lb} / \mathrm{acre}) / \mathrm{yr}]$ & 1.121 & kilogram per hectare per year \\
\hline
\end{tabular}

Temperature in degrees Fahrenheit $\left({ }^{\circ} \mathrm{F}\right)$ and degrees Celsius $\left({ }^{\circ} \mathrm{C}\right)$ may be converted using the following equations:

$$
\begin{aligned}
& { }^{\circ} \mathrm{F}=\left(1.8 \times{ }^{\circ} \mathrm{C}\right)+32 \\
& { }^{\circ} \mathrm{C}=\left({ }^{\circ} \mathrm{F}-32\right) / 1.8
\end{aligned}
$$

Sea level: In this report, "sea level" refers to the National Geodetic Vertical Datum of 1929 (NGVD of 1929) - a geodetic datum derived from a general adjustment of the first-order level nets of both the United States and Canada, formerly called Sea Level Datum of 1929.

Elevation, as used in this report, refers to distance above or below sea level.

Concentrations of chemical constituents in water are given micrograms per liter $(\mu \mathrm{g} / \mathrm{L})$. Micrograms per liter is a unit expressing the concentrations of chemical constituents in solution as weight (micrograms) of solute per unit volume (liter) of water. For concentrations less than 7,000,000 $\mu \mathrm{g} / \mathrm{L}$, the numerical value is the same as for concentrations in parts per billion.

Maximum Contaminant Level (MCL): An enforceable, health-based drinking-water regulation established by the U.S. Environmental Protection Agency.

Method Detection Limit (MDL): The minimum concentration of a substance that can be identified, measured, and reported with a 99-percent confidence that the analyte concentration is greater than zero; determined from analysis of a sample in a given matrix containing analyte. 


\title{
Water-Quality Assessment of the Potomac River Basin: Occurrence of Pesticides in the Great Valley Carbonate Subunit
}

\author{
by Matthew J. Ferrari and Janet M. Denis
}

\section{ABSTRACT}

Multiple sampling approaches were utilized to assess the occurrence and variability of selected pesticides and degradation products in ground water and surface water within the Great Valley Carbonate subunit of the Potomac River Basin as part of the National WaterQuality Assessment Program. Pesticide compounds (pesticides and degradation products) are present at low concentrations (generally less than 1 microgram per liter) in ground water and surface water in the Great Valley Carbonate subunit. Of the 47 pesticide compounds for which water samples were analyzed, 17 compounds were detected in ground-water samples and 24 compounds were detected in surface-water samples. Federal Maximum Contaminant Levels have been established for alachlor, atrazine, carbofuran, lindane, and simazine. No ground-water sample contained pesticide compounds in concentrations above the Maximum Contaminant Levels. Concentrations of atrazine were found above the Maximum Contaminant Level of 3 micrograms per liter in two surface-water samples, and concentrations of simazine were found above the Maximum Contaminant Level of 4 micrograms per liter in a single surface-water sample. Atrazine was the most commonly detected compound in ground-water and surface-water samples, followed by desethylatrazine (a degradation product of atrazine), simazine, metolachlor, and prometon. No other compound was detected in more than 25 percent of the samples.

Concentrations of atrazine, desethylatrazine, and simazine in ground-water and surface-water samples from subunit-scale studies indicate a general north-south variation, with the higher concentrations in the northern part of the Great Valley Carbonate subunit, which also has a higher percentage of cropland. Concentrations of atrazine, desethylatrazine, and simazine in ground-water and surface-water samples all show a significant positive correlation to the percentage of cropland. In addition, concentrations of atrazine in the water samples have a significant positive correlation to the estimated amounts of atrazine used.

As part of an assessment of local patterns in pesticide occurrence and distribution, additional water samples were collected from a shallow ground-water-flow system at Muddy Creek and from domestic wells withị the Muddy Creek watershed. Except for prometon, pesticide compounds that commonly occurred in samples. from the flow-system study and watershed survey were similar to those that were commonly detected in samples from the subunit survey. The highest concentrations of pesticide compounds in the flow-system study were detected in samples from shallow regolith wells near cropped fields. Atrazine concentrations were significantly lower in samples from bedrock wells in the flowsystem study area than in samples from associated regolith wells.

The occurrence and variability in concentration of pesticides at two fixed sites in the Great Valley are dependent upon scale. Throughout the period of sampling at Muddy Creek and Shenandoah River, concentrations of atrazine, desethylatrazine, metolachlor, prometon, and simazine were detected at low levels (generally less than 1 microgram per liter). In general, commonly detected pesticides that are applied to cropland appear to reach their highest concentrations in surface water soon after application, which typically occurs in the spring to early summer each year.

Streamflow at the Muddy Creek fixed site and ground-water levels from one of the regolith-bedrock well pairs from the flow-system study area fluctuate in concert, indicating that there are good connections between the ground-water and surface-water flow systems. In this setting however, concentrations of atrazine were significantly higher in surface-water samples than in ground-water samples. 


\section{INTRODUCTION}

Pesticides, which include herbicides, insecticides, and fungicides, are used extensively to control weeds, insects, and other unwanted organisms in a number of agricultural and non-agricultural settings (Barbash and Resek, 1996). Although the use of pesticides probably has helped increase agricultural yields and reduce the outbreaks of certain diseases, there also is concern among water managers and water users about the potential adverse effects of pesticides on environmental and human health. Some pesticides cause human health problems and can contribute to the degradation of local streams and downstream bodies of water (Barbash and Resek, 1996; Larson and others, 1997).

Pesticides are commonly used throughout the Potomac River Basin and have the potential to contaminate water resources. Dissolved concentrations of selected pesticides and degradation products in water samples from wells and streams in the Potomac River Basin were analyzed to establish the occurrence of pesticides and to relate that occurrence to land-use practices within the Basin.

\section{Purpose and Scope}

The purpose of this report is: (1) to describe the occurrence of 44 pesticides and 3 pesticide degradation products in the Great Valley Carbonate subunit from 1993 through 1995; (2) to describe the spatial and temporal distribution of four commonly detected hydrophilic herbicides (atrazine, metolachlor, prometon, and simazine) and one degradation product (desethylatrazine, a degradation product of atrazine) in the Great Valley Carbonate subunit; (3) to describe the occurrence and distribution of pesticide compounds ${ }^{1}$ using different sampling networks; (4) to compare and relate the occurrence of pesticide compounds in ground and surface water; and (5) to discuss the implications of occurrence of pesticide compounds in terms of human and environmental health, and resource management.

This report documents the occurrence of pesticide compounds in ground water and surface water in the carbonate region of the Great Valley subprovince of the Valley and Ridge Physiographic Province of the Potomac River Basin from 1993 to 1995. Wells and

\footnotetext{
${ }^{1}$ The term "pesticide compounds" in this report refers to both pesticides and degradation products.
}

stream sites in the Great Valley were selected from five different sampling networks used in the Potomac River Basin study (Gerhart and Brakebill, 1996). The percentages of different types of land use in the Great Valley were obtained from available data, and land use within half a mile of each well was mapped in the field. Land use within half a mile of each well and within the contributing watershed for a stream was compared to water quality. Pesticide-use data at the county level were obtained from previously published national pesticide-use estimates.

\section{The National Water-Quality Assessment Program}

The Potomac River Basin is one of 20 initial study units in the National Water-Quality Assessment (NAWQA) Program of the U.S. Geological Survey (USGS). The goals of the NAWQA Program are to assess the status and trends in the water-quality conditions in major aquifer systems and rivers of the Nation, and to link the status and trends with an understanding of the natural and human factors that affect water quality (Gilliom and others, 1995). The data in this report were gathered as part of the NAWQA Program's Potomac River Basin study unit.

\section{The Great Valley Carbonate Subunit}

The Potomac River Basin is in the eastern United States and is part of the Chesapeake Bay drainage system. For study purposes, the basin is divided into eight subunits on the basis of physiography (land form) and lithology (rock type) (Gerhart and Brakebill, 1996). The Great Valley, which is divided into carbonate and noncarbonate subunits, is a part of the Valley and Ridge Physiographic Province. The Great Valley is bounded by the Blue Ridge Mountains to the east and Great North Mountain to the west, and is interrupted by Massanutten Mountain in Virginia (fig. 1). Seventy percent of the Great Valley is underlain by carbonate (limestone and dolomite) bedrock (Denis and Blomquist, 1995), with numerous sinkholes and caverns, which can provide conduits for the rapid movement of chemicals in the subsurface (Barbash and Resek, 1996). The major streams in the Great Valley include the North Fork Shenandoah River, South Fork Shenandoah River, the mainstem Shenandoah River, Opequon Creek, Conococheague Creek, and Antietam Creek 
(fig. 1). In this report, "Great Valley" refers to the carbonate and noncarbonate subunits, whereas "Great Valley Carbonate" refers only to the carbonate subunit.

Agriculture is the predominant land use within the Great Valley Carbonate subunit, and accounts for 75 percent of the total land use (fig. 2); forests cover 15 percent of the subunit, and urban areas cover the remaining 10 percent (Anderson and others, 1976; Denis and Blomquist, 1995). Major agricultural land uses include row crops (corn, wheat, barley, soybeans, and oats), pasture (including hay and alfalfa), orchards (apples and peaches), dairy, and poultry operations (U.S. Department of Commerce, 1995; Gianessi and Puffer, 1990; 1992a,b).

\section{Pesticide Use and Effects}

Major agricultural pesticides used in the Great Valley include atrazine and metolachlor for corn, captan for apples and peaches, and chlorpyrifos for alfalfa, corn, and apples (table 1). Prometon, a non-selective herbicide, is used in noncrop and industrial areas for weed control, but available information on prometon

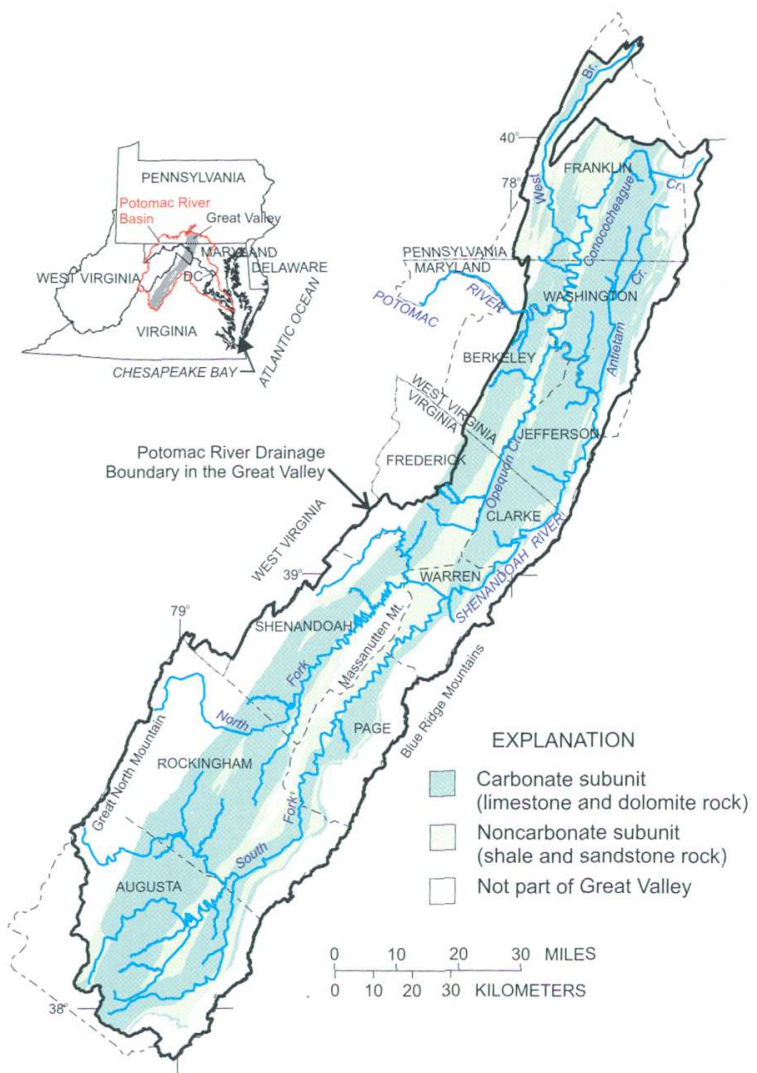

Figure 1. Generalized geology and major tributaries in the Great Valley.

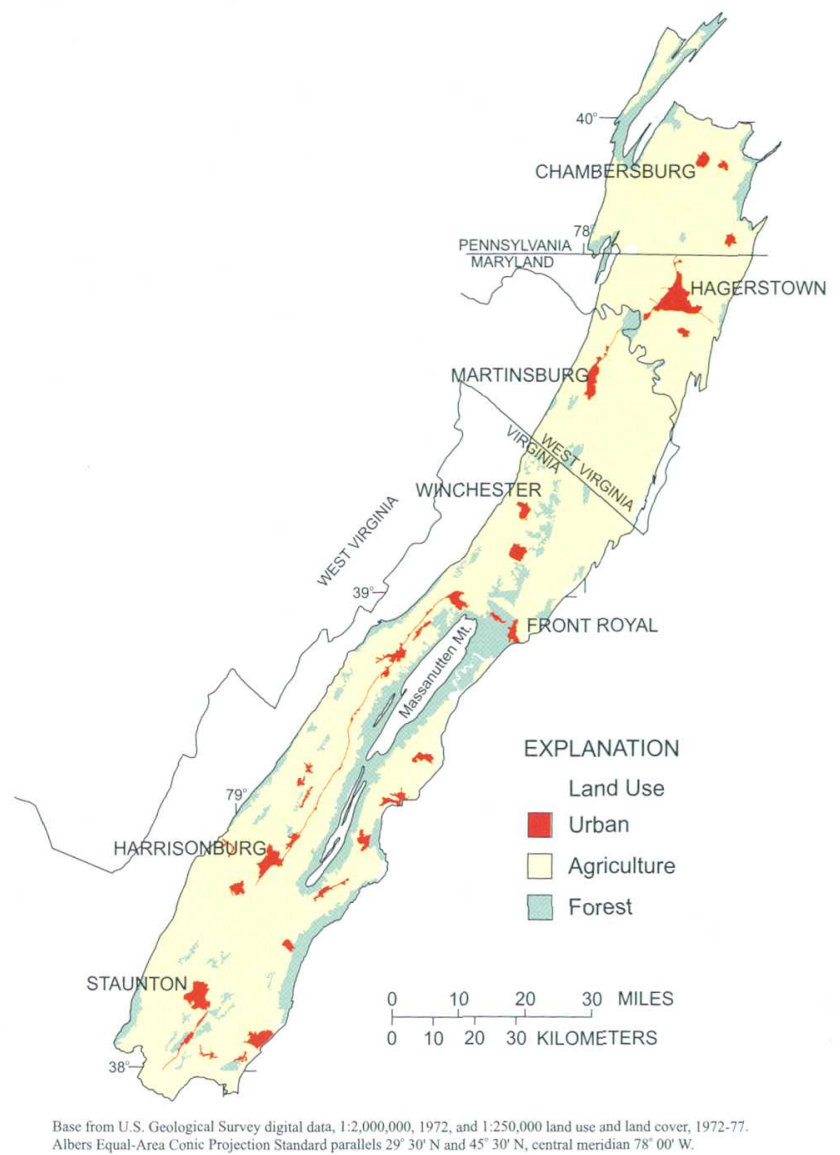

Figure 2. Generalized land use in the Great Valley.

use is insufficient to estimate quantities used in the Great Valley (Roeser, 1988). Information on the nonagricultural use of pesticides is also extremely limited (Barbash and Resek, 1996); nationally, non-agricultural uses of pesticides were estimated to account for 25 percent of the 1.1 billion pounds used in the United States in 1993 (Aspelin, 1994).

Pesticides released into the environment can cause a wide range of ecological and human-health effects. Many pesticides are known or suspected carcinogens and could have toxic effects on humans and aquatic species (U.S. Environmental Protection Agency, 1989; 1990; 1994). Many of the known health effects require exposure to concentrations higher than those that are typically found in the environment, but the health effects of chronic, long-term exposure to low or trace concentrations of individual pesticides or mixtures of these pesticides are generally unknown (Briggs, 1992; Pait and others, 1992). Although some pesticides are designed to be selectively toxic, affecting only a few selected organisms, many pesticides are also toxic to non-target species (Pait and others, 1992). Syn- 
Table 1. The 20 most widely used agricultural pesticides in the Great Valley

[lbs/yr, pounds per year; F, fungicide; H, herbicide; I, insecticide; A, alfalfa; Ap, apples; C, corn; O, other hay; P, pasture; Pe, peaches; S, soybeans]

\begin{tabular}{|c|c|c|c|c|c|}
\hline Pesticide & Trade name 1 & Type & $\begin{array}{l}\text { Estimated } \\
\text { amount } \\
\text { applied } 2,3 \\
\text { (Ibs/yr) }\end{array}$ & $\begin{array}{c}\text { Estimated } \\
\text { acres treated }^{3}\end{array}$ & $\begin{array}{c}\text { Major target } \\
\text { crops }^{3,4}\end{array}$ \\
\hline Atrazine $^{5}$ & AAtrex & $\mathbf{H}$ & 261,000 & 185,000 & $\mathrm{C}$ \\
\hline Metolachlor ${ }^{5}$ & Dual & $\mathbf{H}$ & 177,000 & 103,000 & $\mathrm{C}$ \\
\hline Chlorpyrifos 5 & Dursban & I & 120,000 & 112,000 & $\mathrm{~A}, \mathrm{C}, \mathrm{Ap}$ \\
\hline Mancozeb & Dithane M-45 & $\mathrm{F}$ & 110,000 & 23,300 & Ap \\
\hline $2,4-\mathrm{D}$ & Weed-B-Gon & $\mathbf{H}$ & 100,000 & 170,000 & $\mathrm{P}, \mathrm{O}, \mathrm{C}, \mathrm{Ap}$ \\
\hline Alachlor 5 & Lasso & $\mathbf{H}$ & 89,300 & 50,900 & $\mathrm{C}, \mathrm{S}$ \\
\hline Metiram & Polyram & $\mathrm{F}$ & 86,400 & 4,800 & Ap \\
\hline Carbofuran $^{5}$ & Furadan & I & 64,100 & 67,400 & $A, C$ \\
\hline Ziram & Vancide & $\mathrm{F}$ & 61,700 & 10,400 & Ap \\
\hline Paraquat & Cyclone & $\mathrm{H}$ & 54,300 & 127,000 & $\mathrm{C}, \mathrm{Ap}, \mathrm{A}$ \\
\hline Cyanazine $^{5}$ & Bladex & $\mathbf{H}$ & 53,500 & 36,500 & $\mathrm{C}$ \\
\hline Butylate $^{5}$ & Genate Plus & $\mathrm{H}$ & 52,200 & 11,500 & $\mathrm{C}$ \\
\hline Azinphos-methyl ${ }^{5}$ & Guthion & I & 48,800 & 27,300 & Ap \\
\hline Glyphosate & Roundup & $\mathbf{H}$ & 43,600 & 41,100 & $\mathrm{C}, \mathrm{Ap}, \mathrm{P}$ \\
\hline EPTC $^{5}$ & Eptam & $\mathrm{H}$ & 38,800 & 8,890 & $\mathrm{C}, \mathrm{A}$ \\
\hline Dicamba & Metambane & $\mathbf{H}$ & 33,900 & 107,000 & $\mathrm{P}, \mathrm{C}, \mathrm{O}$ \\
\hline Methomyl & Lannate & I & 33,500 & 31,500 & Ap \\
\hline Methyl parathion $^{5}$ & Penncap-M & $\mathbf{I}$ & 30,200 & 6,950 & Ap \\
\hline
\end{tabular}

${ }^{1}$ Any use of trade names is for descriptive purposes only and does not imply endorsement by the U.S. Geological Survey.

2 Amount of active ingredient.

${ }^{3}$ Gianessi and Puffer 1990; 1992a, 1992b.

${ }^{4}$ Crops with at least 5 percent of the total amount of pesticide applied, in descending order.

${ }^{5}$ Pesticide analyzed for using gas chromatography/mass spectrometry described by Zaugg and others (1995).

ergistic effects (additive effects of similar or related compounds), as well as the processes of bioaccumulation, bioconcentration, and biomagnification, which entail the uptake and accumulation of chemical substances by organisms through the food chain, also are not clearly understood (Briggs, 1992). Furthermore, information on degradation products is limited, with the majority of research focused on acute toxicity, and as with the parent compounds, very little is known about the biological effects of chronic exposure to degradation products. (Barbash and Resek, 1996). Therefore, it is important that the occurrence and distribution of these compounds in surface water and ground water at least be documented and assessed in relation to probable sources.

\section{Acknowledgments}

The authors would like to thank homeowners in the Great Valley who allowed the USGS access to sample wells and streams. The following USGS personnel are also thanked for their contributions and assistance: P. Michael Shackelford for mapping land use at the well locations; Sarah Kelley and Colleen Donnelly for drafting of figures and tables; Lloyd Reed and Michael Koterba for colleague reviews; and Patricia Lietman for additional technical comments. 


\section{METHODS OF STUDY}

The sampling design for the Great Valley subunit was developed to obtain information on the spatial distribution and occurrence of pesticides at several different scales and is part of an assessment of the entire Potomac River Basin. Gerhart and Brakebill (1996) describe the basinwide sampling strategy and the sampling approaches used for this assessment. In addition, part of this design was developed specifically to obtain information on the temporal variability in pesticide occurrence between 1993 and 1995. Water samples collected for this purpose were obtained using tracelevel protocols (Koterba and others, 1995; Shelton, 1994) and analyzed for 44 pesticides, 3 degradation products, and other physical and chemical properties. Pesticide analyses were done by the U.S. Geological Survey's National Water-Quality Laboratory (NWQL).

\section{Ground-Water Sampling}

The sampling approach for ground water included the collection of samples from well networks designed to reflect several different spatial scales (Gilliom and others, 1995). These networks included: (1) a subunit survey that consisted of 29 wells spatially distributed throughout the Great Valley Carbonate subunit (fig. 3); (2) a watershed survey that consisted of nine wells spatially distributed in a 14.2-square-mile $\left(\mathrm{mi}^{2}\right)$

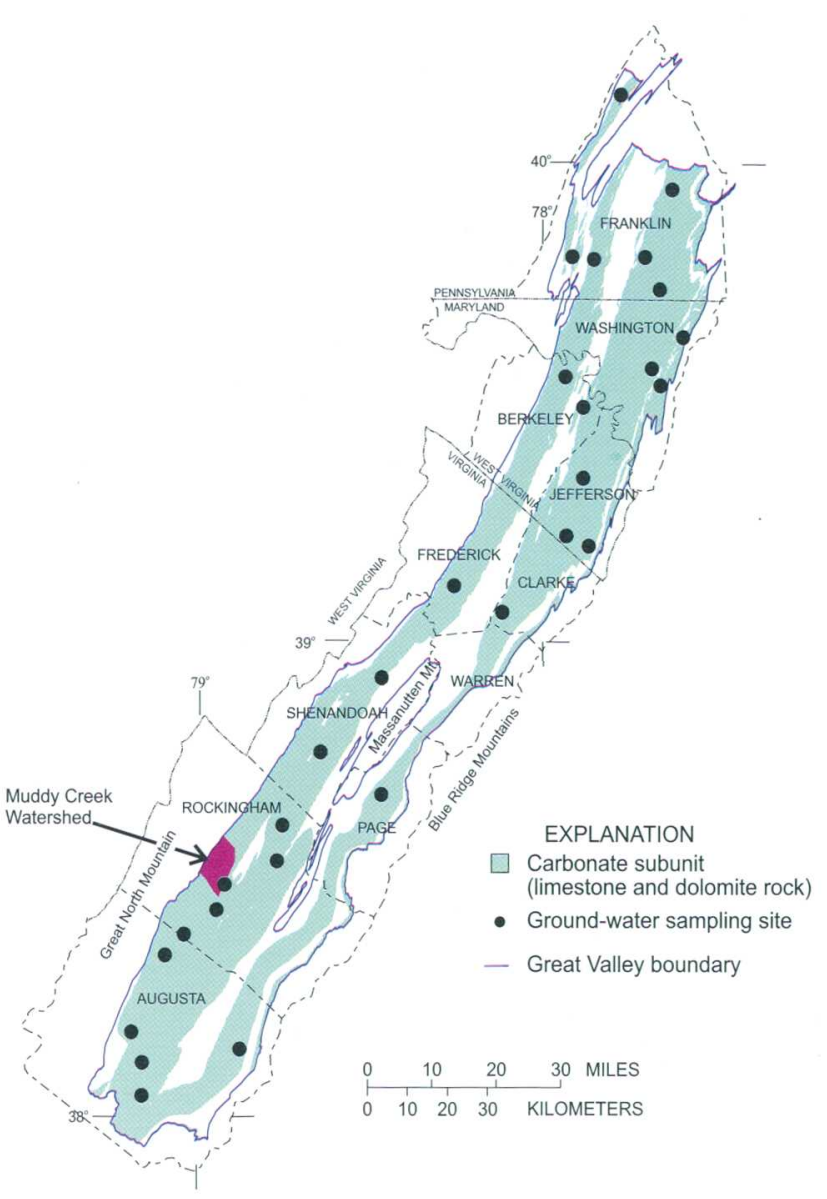

Figure 3. Ground-water sampling locations in the Great Valley Carbonate subunit.

Table 2. Ground-water sampling networks and design for the Great Valley Carbonate subunit, 1993-1995 $\left[\mathrm{mi}^{2}\right.$, square miles; ft, feet]

\begin{tabular}{|c|c|c|c|c|c|c|}
\hline $\begin{array}{l}\text { Sampling } \\
\text { network }\end{array}$ & $\begin{array}{c}\text { Number of } \\
\text { wells }\end{array}$ & $\begin{array}{l}\text { Spatial scale } \\
\qquad\left(\mathrm{mi}^{2}\right)\end{array}$ & $\begin{array}{l}\text { Temporal } \\
\text { scale }\end{array}$ & $\begin{array}{l}\text { Period of } \\
\text { sampling }\end{array}$ & $\begin{array}{c}\text { Number of } \\
\text { samples }\end{array}$ & $\begin{array}{c}\text { Range of well } \\
\text { depths (ft) }\end{array}$ \\
\hline $\begin{array}{l}\text { Subunit } \\
\text { survey }\end{array}$ & 29 & $\begin{array}{l}2,220 \\
\text { (large) }\end{array}$ & one time & $\begin{array}{c}\text { June- } \\
\text { Sept. } 1993\end{array}$ & 29 & $65-290$ \\
\hline $\begin{array}{l}\text { Watershed } \\
\text { survey }\end{array}$ & 9 & $\begin{array}{c}14.2 \\
\text { (intermediate) }\end{array}$ & one time & $\begin{array}{c}\text { May 31-June } \\
8,1995\end{array}$ & 9 & $35-300$ \\
\hline $\begin{array}{l}\text { Flow-system } \\
\text { study }\end{array}$ & 16 & $\begin{array}{c}0.5 \\
\text { (small) }\end{array}$ & seasonally & $\begin{array}{l}\text { April 1994- } \\
\text { June } 1995\end{array}$ & 74 & $\begin{array}{l}\text { 10-78 (regolith) } \\
40-99 \text { (bedrock) }\end{array}$ \\
\hline
\end{tabular}




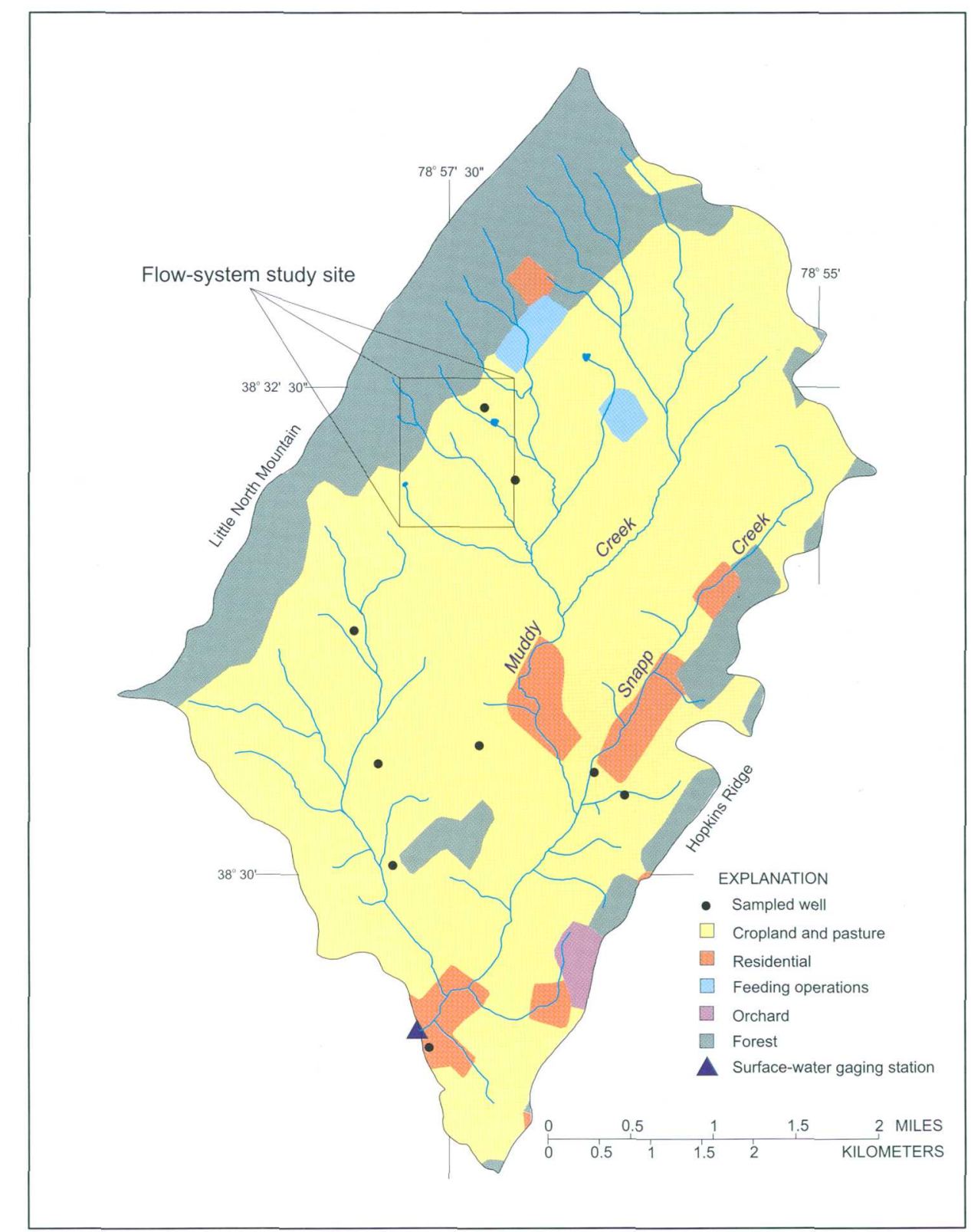

Figure 4. Locations of the sampled wells, surface-water gaging station, general land use, and flow-system study site within the Muddy Creek watershed.

consisted of 16 wells in a half square-mile area (Gerhart and Brakebill, 1996; fig. 5). Samples were collected once from the subunit-survey and watershedsurvey wells to assess the pesticide occurrence and distribution at large to intermediate scales. Samples were collected from the flow-system wells over a 14-month period to assess the spatial occurrence and temporal variability at a small scale (table 2).

For the subunit survey, the 29 randomly selected domestic wells were sampled during the summer of 1993. These wells were relatively shallow (less than 300 feet deep) and the land use in the vicinity of each well was mostly agricultural as row crops or pasture. The same criteria were used to select nine domestic wells within the Muddy Creek watershed, which is within the Shenandoah River Basin, for sampling in late spring 1995.

As part of a small-scale ground-water flow-system study (Gilliom and others, 1995; Lapham and others, 1997), 16 shallow wells were installed in a half square-mile area within the Muddy Creek watershed (fig. 5). Two of the wells (39S 10 and 39S 16) were completed at relatively shallow depths from land surface beneath the water table in regolith (unconsolidated 


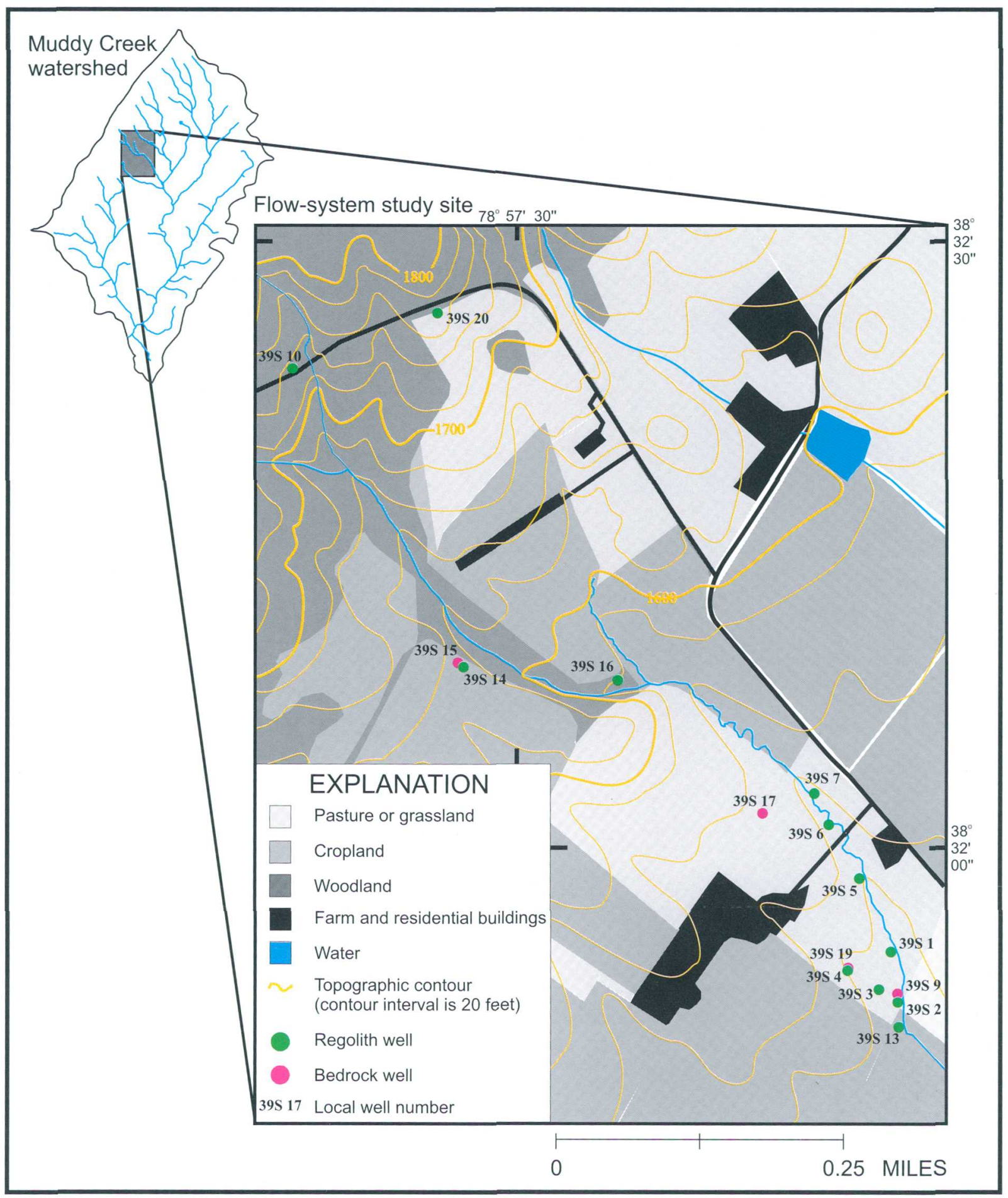

Figure 5. Well network, topography, and land use at the Muddy Creek flow-system study site. 
rock material covering bedrock). Ten wells were screened at the water table in the contact zone between the regolith and the bedrock, and four wells were completed at deeper depths in the upper part of bedrock. Three of the four bedrock wells were installed adjacent to another well that was screened in the overlying regolith. These two-well combinations are referred to as "paired wells". All of the wells were instrumented with water-level recorders set to a 30 -minute recording interval. Water samples were collected periodically between April 1994 and June 1995.

\section{Surface-Water Sampling}

Two sampling approaches were used to assess the quality of surface water in the Great Valley (table 3 ). One of the sampling approaches was the subunit synoptic survey, conducted during base-flow conditions over a 2-week period. For this report, the primary objective of the Great Valley Carbonate subunit synoptic survey was to determine the occurrence and distribution of pesticides in streams draining watersheds ranging from 5 to 20 square miles (fig. 6) and representing the major land uses within the subunit. Data from the subunit synoptic survey ( 25 stream samples) and land-use survey ( 29 ground-water samples) were used to compare pesticide occurrence and distribution between surface and ground water in the Great Valley Carbonate subunit.

The second surface-water sampling approach was the fixed site network, which included integrator and indicator sites. One objective of sampling in the fixed site network was to determine the spatial occurrence and temporal variability of pesticides (Gilliom and others, 1995). Shenandoah River at Millville, W. Va., is a fixed integrator site that drains many land uses and physiographic conditions in the southern part of the Great Valley. Muddy Creek at Mount Clinton, Va., is a fixed indicator site that drains predominantly agricultural land use underlain primarily by carbonate rock in the Great Valley. The watersheds for these two fixed sites are nested. Samples were collected more frequently to improve the probability of detecting pesticides at Muddy Creek, where streamflow responds more quickly to precipitation, than does Shenandoah River.

Table 3. Surface-water sampling networks and design for the Great Valley Carbonate subunit, 1993-1995 $\left[\mathrm{mi}^{2}\right.$, square miles]

\begin{tabular}{|c|c|c|c|c|c|}
\hline Sampling network & $\begin{array}{l}\text { Number of } \\
\text { pesticide } \\
\text { sampling } \\
\text { sites within } \\
\text { the Great } \\
\text { Valley } \\
\text { Carbonate } \\
\text { subunit }\end{array}$ & $\begin{array}{c}\text { Spatial } \\
\text { scale } \\
\left(\mathbf{m i}^{2}\right)\end{array}$ & $\begin{array}{l}\text { Temporal } \\
\text { scale }\end{array}$ & $\begin{array}{l}\text { Period of } \\
\text { sampling }\end{array}$ & $\begin{array}{c}\text { Number of } \\
\text { samples }\end{array}$ \\
\hline Subunit synoptic survey & 25 & 2,220 & one time & Sept. 7-15, 1993 & 25 \\
\hline \multicolumn{6}{|l|}{ Fixed Site Network } \\
\hline $\begin{array}{l}\text { Integrator } \\
\text { (Shenandoah River at Millville, W. Va.) }\end{array}$ & 1 & $\begin{array}{c}3,040 \\
\text { (large) }\end{array}$ & monthly & $\begin{array}{l}\text { March 1993- } \\
\text { July } 1995\end{array}$ & 19 \\
\hline $\begin{array}{l}\text { Land-use indicator } \\
\text { (Muddy Creek at Mount Clinton, Va.) }\end{array}$ & 1 & $\begin{array}{c}14.2 \\
\text { (small) }\end{array}$ & weekly to monthly & $\begin{array}{l}\text { March 1993- } \\
\text { May 1995 }\end{array}$ & 39 \\
\hline
\end{tabular}




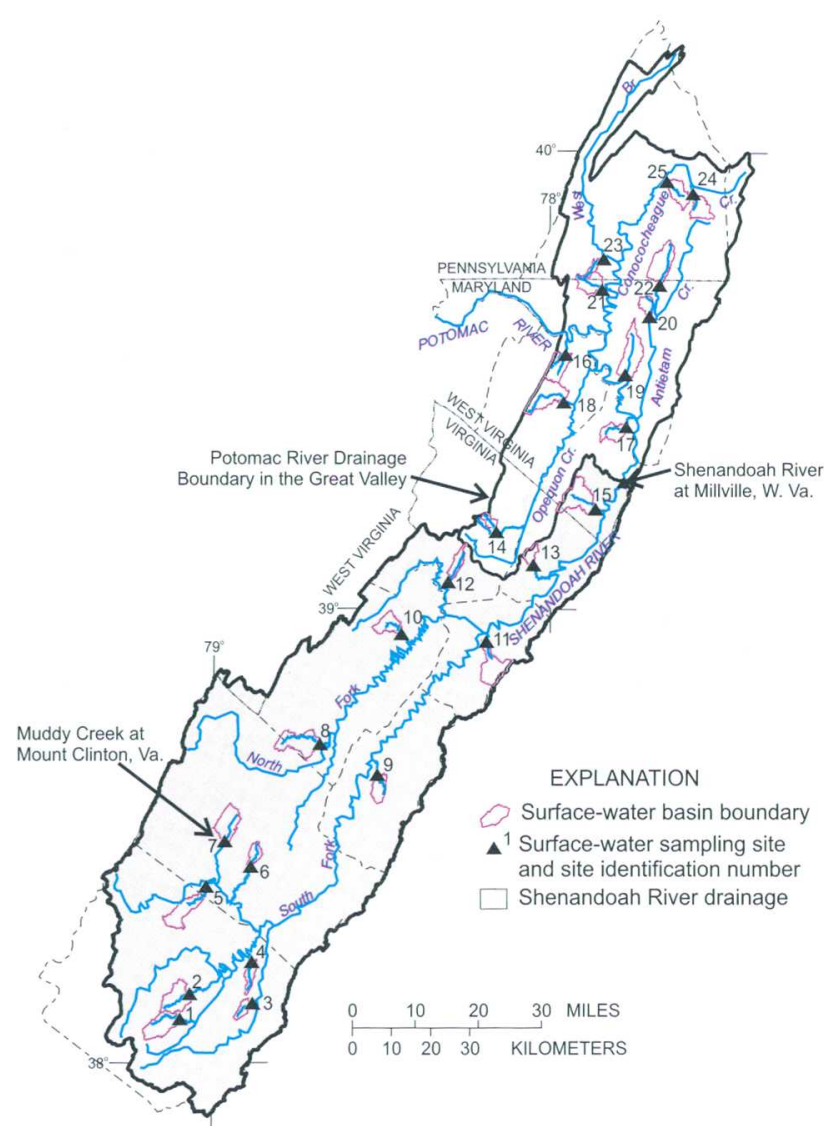

Figure 6. Surface-water sampling sites in the Great Valley.

\section{Data Analysis}

Water samples were analyzed for 44 pesticides and 3 pesticide degradation products at the USGS NWQL using gas chromatography and mass spectrometry (Zaugg and others, 1995). This list of 47 pesticide compounds was developed on the basis of information about the widespread use of pesticides in the United States and pesticides of national importance. This analytical method allows for the quantification of detected analytes within a level of uncertainty expressed as the method detection limit (MDL). The MDL is the minimum concentration of a substance that can be identified, measured, and reported with a 99-percent confidence that the analyte concentration is greater than zero (Wershaw and others, 1987). Some pesticide concentrations were reported by the NWQL as an estimated value. The data cited in this report include two different types of estimated values. The first type, which includes many of the reported concentrations of prometon, has values reported less than the MDL. In this case, the pesticide is qualitatively identified, but the quantification has a larger uncertainty associated with it than the quantifications above the MDL (Jeffrey Pritt, U.S. Geological Survey, written commun., 1994). The second type of estimated value is typified by the reported concentrations of desethylatrazine, in which all of the concentrations are reported as estimated values due to the poor analytical response of the compound in this method (Chris Lindley, U.S. Geological Survey, written commun., 1997). For this study, estimated concentrations of pesticides were considered detections of those compounds.

Although all samples were analyzed for 47 pesticide compounds, most of the data analysis and interpretation in this report focuses on 5 compounds: atrazine, desethylatrazine, metolachlor, prometon, and simazine. Only these five compounds were detected in at least 50 percent of ground-water and surface-water subunit samples.

Descriptions of statistical summaries, boxplots, Spearman's rho correlations, contingency tables, Kruskal-Wallis, rank sum tests, and Tukey tests are described in Helsel and Hirsch (1992). Because waterquality data are rarely distributed normally, nonparametric tests such as the Kruskal-Wallis test were used. For the purposes of nonparametric statistical testing, concentrations of atrazine, desethlyatrazine, metolachlor, and simazine reported as less than the MDL were set to one-half the MDL. Estimated concentrations of prometon, reported as values below the MDL and detections above the MDL, were grouped as detects when using the contingency table test (Helsel and Hirsch, 1992, p. 375). All detections of desethylatrazine are qualitatively identified and reported as an estimated value (Zaugg and others, 1995). Null hypotheses were accepted or rejected at the 90-percent confidence level (alpha $=0.10$ ). This confidence level was chosen because of the relatively small sample size in relation to the area sampled and the uncertainties in the pesticide-use data, land-use statistics, and for ground water, uncertainty in the delineation of the contributing area.

Field blanks, replicates, and spikes were collected to determine uncertainty and variability in the data as described in NAWQA protocols (Koterba and others, 1995; Shelton, 1994; Mueller and others, 1997). A field blank is used to identify the reliability of concentrations reported at, near, or below analytical detection limits. None of the five compounds of interest -atrazine, desethylatrazine, metolachlor, prometon, and simazine -- were detected in ground-water and surfacewater field blanks collected in the Great Valley. This 
suggests that no contamination from previous sample collection and processing nor from laboratory processing and analysis was introduced. Replicate sample data were pooled for each sample medium (ground water or surface water) to obtain an estimate of standard deviation for each of the five pesticide compounds (Taylor, 1987). Replicates are used to assess the sources of variability caused by short-term environmental fluctuations (Mueller and others, 1997). The variability within each sample medium is low, indicating good sample handling, processing, and analysis procedures. When comparing ground water to surface water, however, the variability in concentrations of atrazine and desethylatrazine is higher in ground water than in surface water, whereas the variability of metolachlor and simazine is lower in ground water than in surface water (table 4). Water samples were fortified with a known quantity of selected pesticides to determine whether the analytical methodology measured all of the analyte contained in the sample (Mark Sandstrom, U.S. Geological Survey, written commun., 1995). Except for prometon, mean recoveries for each pesticide compound are similar for ground water and surface water. Mean recoveries for atrazine are similar to values published by Zaugg and others (1995), but mean recoveries for metolachlor, simazine, and desethylatrazine are higher than published values, possibly indicating the analytical methodologies improved for these compounds.

Concentrations of prometon were detected both below and above the MDL (0.018 micrograms per liter, $\mu \mathrm{g} / \mathrm{L})$.

The concentrations of pesticides in ground water were compared to percentages of different land uses within half a mile of the Great Valley Carbonate subunit wells. High-altitude aerial photography obtained from the National Aerial Photography Program (scale approximately 1:20,000; U.S. Geological Survey, 1996) was used to help map, field check, and classify land use surrounding each of the Great Valley Carbonate subunit and Muddy Creek watershed wells. The areal extent of each land use relative to the total area

Table 4. Results of analyses of quality-control samples, ground water and surface water, in the Great Valley Carbonate subunit, 1993 to 1995

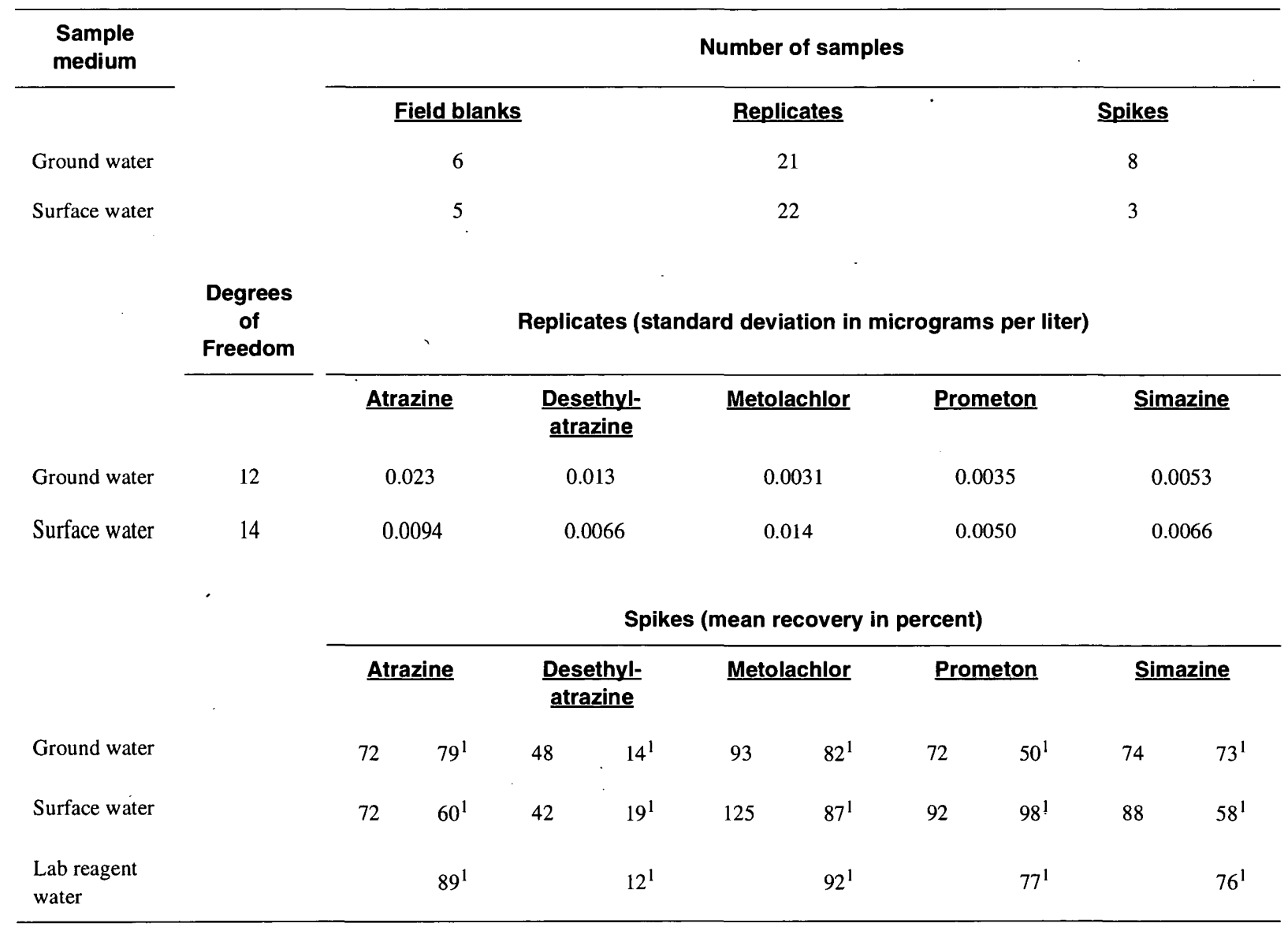

${ }^{1}$ Published mean recovery data at 0.1 micrograms per liter from Zaugg and others, 1995. 
Table 5. County agricultural land-use statistics ${ }^{1}$ for the Great Valley

[All values are in acres].

\begin{tabular}{llcccccccccc}
\hline State & County & $\begin{array}{c}\text { Harvested } \\
\text { corn }\end{array}$ & $\begin{array}{c}\text { Harvested } \\
\text { soybeans }\end{array}$ & $\begin{array}{c}\text { Harvested } \\
\text { alfalfa }\end{array}$ & Apples & Cherries & Peaches & Pears & $\begin{array}{c}\text { Harvested } \\
\text { cropland }\end{array}$ & $\begin{array}{c}\text { Total } \\
\text { pasture }\end{array}$ & $\begin{array}{c}\text { Land in } \\
\text { orchards }\end{array}$ \\
\hline Maryland & Washington & 21,439 & 6,339 & 10,952 & 1,264 & 24 & 437 & 11 & 72,406 & 31,273 & 1,787 \\
Pennsylvania & Franklin & 44,375 & 6,990 & 33,592 & 4,616 & 120 & 944 & 39 & 162,103 & 36,081 & 5,874 \\
Virginia & Augusta & 11,576 & 1,241 & 15,798 & 168 & 1 & 7 & 0 & 78,525 & 167,756 & 255 \\
Virginia & Clarke & 2,069 & 963 & 4,008 & 3,294 & 0 & 0 & 0 & 24,571 & 35,198 & 3,296 \\
Virginia & Frederick & 2,644 & 210 & 4,318 & 9,068 & 0 & 615 & 24 & 34,585 & 40,972 & 9,743 \\
Virginia & Page & 3,601 & 112 & 3,214 & 33 & 0 & 13 & 0 & 18,506 & 33,755 & 57 \\
Virginia & Rockingham & 16,455 & 2,165 & 13,469 & 1,873 & 16 & 200 & 3 & 85,802 & 112,726 & 2,150 \\
Virginia & Shenandoah & 5,262 & 2,046 & 6,183 & 2,539 & 5 & 71 & 0 & 39,087 & 56,908 & 2,668 \\
Virginia & Warren & 129 & 0 & 1,703 & 0 & 0 & 0 & 0 & 9,592 & $.21,137$ \\
West Virginia & Berkeley & 3,242 & 821 & 5,062 & 6,593 & 14 & 1,460 & 22 & 30,324 & 26,016 & 8,132 \\
West Virginia & Jefferson & 10,140 & 3,836 & 5,107 & 1,906 & 0 & 468 & 0 & 37,226 & 25,574 & 2,497 \\
\hline
\end{tabular}

${ }^{\prime}$ U.S. Department of Commerce, 1995.

within half a mile of the well was used to calculate the percentage of each identified land use (cropland, pasture, residential, farm buildings, poultry houses, orchards, roads, and so forth) within the half-mile radius (Ferrari and Ator, 1995).

The average mapped land-use percentages for the well sites were consistent with previously reported land-use percentages for the entire Great Valley Carbonate subunit (Anderson and others, 1976). This indicates that the well sites are representative of the land uses found in the Great Valley Carbonate subunit.

The concentrations of pesticides in ground water were compared to estimates of pesticide use within half a mile of the wells. These pesticide-use estimates were calculated using county crop statistics from the 1992 Census of Agriculture (table 5) and the county pesticide-use statistics from Gianessi and Puffer (1990) (table 6), in combination with the land-use percentages within half a mile of the wells. For example, to calculate the amount of atrazine used, the percentage of each county's cropland devoted to corn was determined by dividing the acres of harvested corn by the acres of harvested cropland. Assuming that the same percentage of cropland within half a mile of the wells is devoted to corn, the number of acres of corn was calculated by multiplying the acres of cropland in the half-mile
Table 6. County agricultural pesticide-use estimates ${ }^{1}$ for the Great Valley

[All values in pounds of active ingredient]

\begin{tabular}{|c|c|c|c|c|}
\hline \multirow{2}{*}{ State } & \multirow{2}{*}{ County } & \multicolumn{3}{|c|}{ Pesticide } \\
\hline & & Atrazine & Metolachlor & Simazine \\
\hline Pennsylvania & Franklin & 85,800 & 67,700 & 4,940 \\
\hline Maryland & Washington & 47,000 & 34,900 & 10,400 \\
\hline \multirow[t]{3}{*}{ West Virginia } & Berkeley & 9,660 & 3,280 & 3,420 \\
\hline & Jefferson & 21,800 & 7,760 & 4,700 \\
\hline & - & & & \\
\hline \multirow[t]{7}{*}{ Virginia } & Augusta & 28,800 & 18,900 & 9,810 \\
\hline & Clarke & 6,080 & 4,000 & 5,660 \\
\hline & Frederick & 5,410 & 3,600 & 18,700 \\
\hline & Page & 6,130 & 4,040 & 2,110 \\
\hline & Rockingham & 38,600 & 25,300 & 15,600 \\
\hline & Shenandoah & 10,600 & 7,210 & 6,810 \\
\hline & Warren & 820 & 540 & 1,930 \\
\hline
\end{tabular}

${ }^{1}$ Estimates of annual agricultural usage, from Gianessi and Puffer, 1990. 
radius by the county-level percentage of cropland devoted to corn. The amount of atrazine used within the half-mile radius was calculated by multiplying the acres devoted to corn by the percent of acres treated and the rate of application (table 7). The same procedure was used to calculate the amount of metolachlor applied to corn and soybeans. Simazine applications to corn, alfalfa, and several orchard crops (apples, cherries, peaches, and pears) were calculated by use of a similar method. However, additional assumptions were needed to calculate the amount of simazine applied to alfalfa crops. Because land used to grow alfalfa was indistinguishable from pasture during the field mapping, the county percentage devoted to alfalfa was calculated by dividing the harvested acres of alfalfa by the sum of the acres of harvested cropland and the acres of pasture. This percentage was then multiplied by the sum of cropland and pasture within the half-mile radius to produce the estimated number of acres of alfalfa.

Land-use percentages for the Great Valley and the drainage areas for two fixed sites were obtained from the Anderson Level I land-use classification system used in the Geographic Information Retrieval and Analysis System (GIRAS) (Mitchell and others, 1977). The urban land-use class was updated by Hitt (1994) with 1990 U.S. population census data. Census blocks representing population densities greater than 1,000 people per square mile were considered to be urban and were added to the data set.

Pesticide concentrations from the 25 surfacewater subunit synoptic watersheds were analyzed in relation to land-use data for each watershed. Land-use data were compiled from GIRAS Anderson Level I land-use classification (Anderson and others, 1976), Virginia Geographic Information System (Virginia Department of Conservation and Recreation, 1989), Maryland's Automated Geographic Information System (Maryland Office of State Planning, 1991), Natural Resources Conservation Service, Jefferson County, W. Va., and interpreted aerial photographs to obtain the following land-use classes: cropland, pasture, forest, urban, and other.

The concentrations of pesticides in surface water were compared to estimates of pesticide use for the contributing watersheds. The procedures used to estimate pesticide usage within each contributing watershed were similar to those used to calculate pesticide usage within half a mile of the sampled wells. The same assumptions concerning land uses and crops were used for consistency in the data analysis. One additional assumption was made for the surface-water pesticide analysis. Because several of the watersheds spanned parts of more than one county, crop percentages were assigned to these watersheds on the basis of which county contained most of the watershed area.

Table 7. Examples of estimated atrazine applications within half a mile of four wells in the Great Valley Carbonate subunit

\begin{tabular}{|c|c|c|c|c|c|c|c|c|c|}
\hline \multirow[b]{2}{*}{ State } & \multirow[b]{2}{*}{ County } & \multicolumn{3}{|c|}{ County } & \multicolumn{2}{|c|}{ Half-mile radius } & \multicolumn{3}{|c|}{ Atrazine application } \\
\hline & & $\begin{array}{c}\text { Corn } \\
\text { (harvested } \\
\text { acres) }^{1}\end{array}$ & $\begin{array}{c}\text { Cropland } \\
\text { (harvested } \\
\text { acres) }^{1}\end{array}$ & $\begin{array}{l}\text { Corn } \\
\text { (percent of } \\
\text { cropland) }\end{array}$ & $\begin{array}{c}\text { Cropland } \\
\text { (acres) }\end{array}$ & $\begin{array}{c}\text { Corn } \\
\text { (acres) }\end{array}$ & $\begin{array}{l}\text { Acres treated } \\
\text { (percent of } \\
\text { corn acres) }\end{array}$ & $\begin{array}{l}\text { Application } \\
\text { rate (pounds } \\
\text { per acre) }\end{array}$ & $\begin{array}{c}\text { Amount } \\
\text { applied } \\
\text { (pounds) }\end{array}$ \\
\hline Pennsylvania & Franklin & 44,375 & 162,103 & 27.37 & 464.5 & 127.1 & 83 & 1.27 & 134 \\
\hline Maryland & Washington & 21,439 & 72,406 & 29.61 & 377.4 & 111.8 & 90 & 1.5 & 151 \\
\hline West Virginia & Jefferson & 10,140 & 37,226 & 27.24 & 162.18 & 44.18 & 91 & 1.5 & 60 \\
\hline Virginia & Augusta & 11,576 & 78,525 & 14.74 & 105.2 & 15.5 & 78 & 1.48 & 18 \\
\hline
\end{tabular}




\section{PESTICIDES IN GROUND WATER AND SURFACE WATER}

Many different pesticide compounds were detected in ground-water and surface-water samples from the Great Valley Carbonate subunit. Of the 47 pesticide compounds analyzed, 36 percent of the compounds were detected in ground-water samples and 51 percent of the compounds were detected in surfacewater samples (table 8). Atrazine, desethylatrazine, simazine, metolachlor, and prometon were the most commonly detected pesticide compounds in ground- water and surface-water samples (table 9). No other pesticide was detected in more than 25 percent of the samples.

The most commonly detected pesticides in the Great Valley are among those that are most commonly applied. Eleven of the 20 most widely used agricultural pesticides (table 1) were analyzed for using the method of analysis described by Zaugg and others (1995). Two additional pesticides (2,4-D and methomyl) were analyzed using another method and are not included in the scope of this report. Thus, no data were collected on the

Table 8. Pesticides and degradation products for which water samples from the Great Valley Carbonate subunit were analyzed

[D, detected; ----, not detected; GW, ground water; SW, surface water]

\begin{tabular}{|c|c|c|c|c|c|}
\hline \multirow{2}{*}{ Compound } & \multicolumn{2}{|c|}{ Sample type } & \multirow{2}{*}{ Compound } & \multicolumn{2}{|c|}{ Sample type } \\
\hline & GW & SW & & GW & SW \\
\hline Acetochlor & ---- & ---- & Malathion & $\mathrm{D}$ & $\mathrm{D}$ \\
\hline Alachlor & $\mathrm{D}$ & $\mathrm{D}$ & Methyl parathion & ---- & ---- \\
\hline Atrazine & D & $\mathrm{D}$ & Metolachlor & $\mathrm{D}$ & $\mathrm{D}$ \\
\hline Azinphos-methyl & --- & --- & Metribuzin & $\mathrm{D}$ & $\mathrm{D}$ \\
\hline Benfluralin & .... & $\ldots$ & Molinate & ---- & ---- \\
\hline Butylate & --- & $\mathrm{D}$ & Napropamide & --- & D \\
\hline Carbaryl & ---- & $\mathrm{D}$ & Parathion & ---- & ---- \\
\hline Carbofuran & --- & $\mathrm{D}$ & Pebulate & $\mathrm{D}$ & ---- \\
\hline Chlorpyrifos & $\mathrm{D}$ & $\mathrm{D}$ & Pendimethalin & --- & --- \\
\hline Cyanazine & $\cdots-$ & $\mathrm{D}$ & Permethrin & ---- & ---- \\
\hline DCPA & $\mathrm{D}$ & $\mathrm{D}$ & Phorate & ---- & --- \\
\hline p,p'-DDE & $\mathrm{D}$ & $\mathrm{D}$ & Prometon & D & $\mathrm{D}$ \\
\hline Desethylatrazine & $\mathrm{D}$ & $\mathrm{D}$ & Pronamide & ---- & ---- \\
\hline Diazinon & $\mathrm{D}$ & D & Propachlor & ---- & --- \\
\hline Dieldrin & ---- & ---- & Propanil & $\cdots$ & --- \\
\hline 2,6-Diethylanaline & ---- & $\mathrm{D}$ & Propargite & ---- & --- \\
\hline Disulfoton & $-\cdots$ & ---- & Simazine & $\mathrm{D}$ & $\mathrm{D}$ \\
\hline EPTC & $\mathrm{D}$ & $\mathrm{D}$ & Tebuthiuron & $\mathrm{D}$ & $\mathrm{D}$ \\
\hline Ethalfluralin & $\cdots$ & ---- & Terbacil & D & $\mathrm{D}$ \\
\hline Ethoprop & ---- & D & Terbufos & ---- & ---- \\
\hline Fonofos & $\cdots$ & ---- & Thiobencarb & --.- & ---- \\
\hline alpha-HCH & $\cdots$ & $\cdots$ & Triallate & $-\cdots$ & ---- \\
\hline Lindane & ---- & $-\cdots$ & Trifluralin & D & D \\
\hline Linuron & ---- & D & & & \\
\hline
\end{tabular}


Table 9. Occurrence of pesticides and related compounds in water samples from the Great Valley

\begin{tabular}{|c|c|c|c|c|c|c|c|c|c|c|c|}
\hline & & \multicolumn{7}{|c|}{ Ground-water sampling networks } & \multicolumn{3}{|c|}{$\begin{array}{c}\text { Surface-water sampling } \\
\text { networks }\end{array}$} \\
\hline & & \multirow{3}{*}{$\begin{array}{l}\text { Subunit } \\
\text { survey }\end{array}$} & \multirow{3}{*}{$\begin{array}{l}\text { Watershed } \\
\text { survey }\end{array}$} & \multicolumn{5}{|c|}{ Flow-system study } & \multirow{3}{*}{$\begin{array}{l}\text { Subunit } \\
\text { synoptic } \\
\text { survey }{ }^{1}\end{array}$} & \multirow{2}{*}{\multicolumn{2}{|c|}{ Fixed sites }} \\
\hline & & & & Syno & ptics & Seasonal & sampling & $\begin{array}{c}\text { All } \\
\text { samples }\end{array}$ & & & \\
\hline \multicolumn{2}{|l|}{ - } & & & $\begin{array}{l}\text { Sept. } \\
94\end{array}$ & $\begin{array}{c}\text { June } \\
95\end{array}$ & $\begin{array}{l}\text { Apr. 94- } \\
\text { June } \\
95^{2} .\end{array}$ & $\begin{array}{c}\text { Sept 94- } \\
\text { June } \\
95^{3}\end{array}$ & - & & $\begin{array}{l}\text { Mar 93- } \\
\text { July } \\
94^{4}\end{array}$ & $\begin{array}{l}\text { Mar 93- } \\
\text { May } \\
95^{5}\end{array}$ \\
\hline $\begin{array}{l}\text { Pesticide } \\
\text { compound }\end{array}$ & $M^{\prime} L^{6}$ & \multicolumn{10}{|c|}{ Number of detections } \\
\hline Alachlor & 0.002 & 1 & 0 & 0 & 0 & 0 & 0 & 0 & 2 & 6 & 12 \\
\hline Atrazine & .001 & 25 & 7 & 10 & 11 & 10 & 6 & 59 & 25 & 19 & 39 \\
\hline Butylate & .002 & 0 & 0 & 0 & 0 & 0 & 0 & 0 & 1 & 0 & 1 \\
\hline Carbaryl & .003 & 0 & 0 & 0 & 0 & 0 & 0 & 0 & 4 & 0 & 3 \\
\hline Carbofuran & .003 & 0 & 0 & 0 & 0 & 0 & 0 & 0 & 1 & 0 & 1 \\
\hline Chlorpyrifos & .004 & 0 & 0 & 0 & 0 & 0 & 0 & 2 & 2 & 0 & 0 \\
\hline Cyanazine & .004 & 0 & 0 & 0 & 0 & 0 & 0 & 0 & 3 & 7 & 8 \\
\hline DCPA & .002 & 1 & 0 & 0 & 0 & 0 & 0 & 0 & 1 & 0 & 2 \\
\hline $\mathrm{p}, \mathrm{p}$ '-DDE & .006 & 7 & 0 & 0 & 0 & 0 & 0 & 1 & .2 & 0 & 1 \\
\hline Desethylatrazine & .002 & 24 & 8 & 10 & 10 & 10 & 6 & 57 & 25 & 19 & 39 \\
\hline Diazinon & .002 & 0 & 0 & 2 & 0 & 0 & 0 & 4 & 2 & 1 & 1 \\
\hline $\begin{array}{l}\text { 2,6-Diethylana- } \\
\text { line }\end{array}$ & .003 & 0 & 0 & 0 & 0 & 0 & 0 & 0 & 1 & 0 & 0 \\
\hline EPTC & .002 & 3 & 0 & 0 & 0 & 0 & 0 & 0 & 1 & 0 & 2 \\
\hline Ethoprop & .003 & 0 & 0 & 0 & 0 & 0 & 0 & 0 & 0 & 0 & 1 \\
\hline Linuron & .002 & 0 & 0 & 0 & 0 & 0 & 0 & 0 & 1 & 0 & 0 \\
\hline Malathion & .005 & 0 & 0 & 1 & 0 & 0 & 0 & 1 & 1 & 0 & 1 \\
\hline Metolachlor & .002 & 15 & 4 & 8 & 8 & 6 & 3 & 41 & 25 & 19 & 35 \\
\hline Metribuzin & .004 & 1 & 0 & 0 & 0 & 0 & 0 & 2 & 2 & 0 & 2 \\
\hline Napropamide & .003 & 0 & 0 & 0 & 0 & 0 & 0 & 0 & 1 & 0 & 0 \\
\hline Pebulate & .004 & 1 & 0 & 0 & 0 & 0 & 0 & 0 & 0 & 0 & 0 \\
\hline Prometon & .018 & 15 & 1 & 0 & 0 & 0 & 0 & 0 & 24 & 19 & 19 \\
\hline Simazine & .005 & 19 & 4 & 9 & 9 & 10 & 6 & 52 & 25 & 17 & 37 \\
\hline Tebuthiuron & .010 & 2 & 0 & 1 & 2 & 0 & 0 & 9 & 12 & 8 & 13 \\
\hline Terbacil & .007 & 1 & 0 & 0 & 0 & 0 & 0 & 0 & 1 & 0 & 0 \\
\hline Trifluralin & .002 & 0 & 0 & 2 & 0 & 0 & 0 & 5 & 6 & 1 & 5 \\
\hline \multicolumn{2}{|c|}{ Total number of samples } & 29 & 9 & 12 & 16 & 10 & 6 & 74 & 25 & 19 & 39 \\
\hline \multicolumn{2}{|c|}{$\begin{array}{l}\text { Number of compounds } \\
\text { detected }\end{array}$} & 13 & 5 & 8 & 5 & 4 & 4 & 11 & 23 & 10 & 19 \\
\hline \multicolumn{12}{|c|}{$\begin{array}{l}{ }_{1}^{1} \text { One sample collected at Muddy Creek at Mount Clinto } \\
2 \text { Well 39S 4, regolith. } \\
{ }^{3} \text { Well } 39 \text { S 19, bedrock. } \\
{ }^{4} \text { Shenandoah River at Millville, W. Va., integrator site. } \\
{ }^{5} \text { Muddy Creek at Mount Clinton, Va., indicator site. }\end{array}$} \\
\hline
\end{tabular}


occurrence of 7 of the 20 most widely used pesticides in the Great Valley.

Six of the 20 agricultural pesticides most widely used in the Great Valley were detected in 6 or fewer water samples. Cyanazine, butylate, and carbofuran were detected only in surface-water samples. Alachlor, chlorpyrifos, and EPTC were detected in a few groundwater and surface-water samples. Azinphos-methyl and methyl parathion were not detected in any sample.

\section{Pesticides in Ground Water}

Most of the wells sampled in the Great Valley for the ground-water subunit survey contained measurable (detectable and quantifiable) levels of multiple pesticide compounds, up to a total of six compounds (fig. 7). Of the 29 wells sampled for the subunit survey, $26 \mathrm{had}$ measurable levels of at least 1 pesticide and all but 1 of these samples contained measurable levels of 2 or more compounds. Recent studies have examined the possible link between the occurrence of multiple contaminants in the environment and adverse health effects (Goodbred and others, 1997). Although results are inconclusive, there does appear to be a link between changes in hormone levels in fish and exposure to certain contaminants, including pesticides. Because ground water discharges into streams as base flow, any pesticides dissolved in ground water also discharge into streams and may continue to be a source of contamination to streams for years, even if the application of pesticides is reduced or eliminated.

Atrazine was the most commonly detected pesticide in the ground-water subunit survey (table 9), followed by desethylatrazine, simazine, metolachlor, and prometon. Eight other compounds (alachlor, DCPA, p,p'-DDE, EPTC, metribuzin, pebulate, tebuthiuron, and terbacil) were each detected in fewer than 25 percent of the subunit-survey samples (table 9). None of the ground-water subunit-survey samples contained pesticides in concentrations that were above current Federal Maximum Contaminant Levels (MCL) (U.S. Environmental Protection Agency, 1994).

Concentrations of some of the pesticides commonly detected in ground-water samples indicate a general north-south variation, with the highest concentrations in the northern part of the Great Valley Carbonate subunit (fig. 8). This variation is similar to the geo-

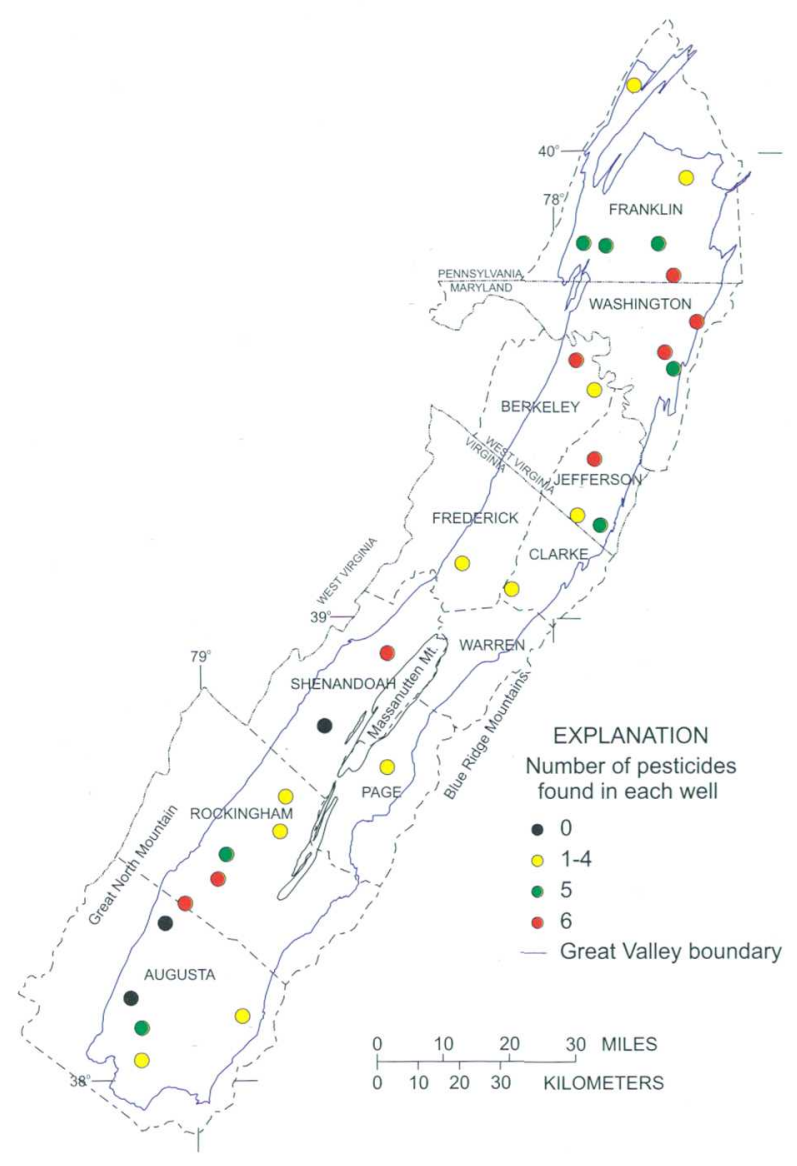

Figure 7. Number of pesticide compounds detected at each ground-water subunit survey well in the Great Valley Carbonate subunit.

graphic distribution of nitrate concentrations in samples collected from the same wells (Ferrari and Ator, 1995). Atrazine exhibits this north-south variation, with a median concentration of $0.148 \mu \mathrm{g} / \mathrm{L}$ for the northern samples (from Pennsylvania, Maryland, and West Virginia) and a median concentration of $0.037 \mu \mathrm{g} / \mathrm{L}$ for the southern samples from Virginia. A rank sum test of these two groups of samples showed the differences to be significant ( $\mathrm{p}=0.0555$; fig. 9 ). The geographical differences are also significant for desethylatrazine and simazine ( $\mathrm{p}=0.0835$ and $\mathrm{p}=0.0402$, respectively). No significant geographical difference was found for metolachlor $(\mathrm{p}=0.3636)$.

Concentrations of atrazine, desethylatrazine, and simazine all indicate a positive correlation to the percentage of cropland and a negative correlation to the percentage of pasture around the wells (table 10); concentrations of metolachlor indicate no significant corre- 


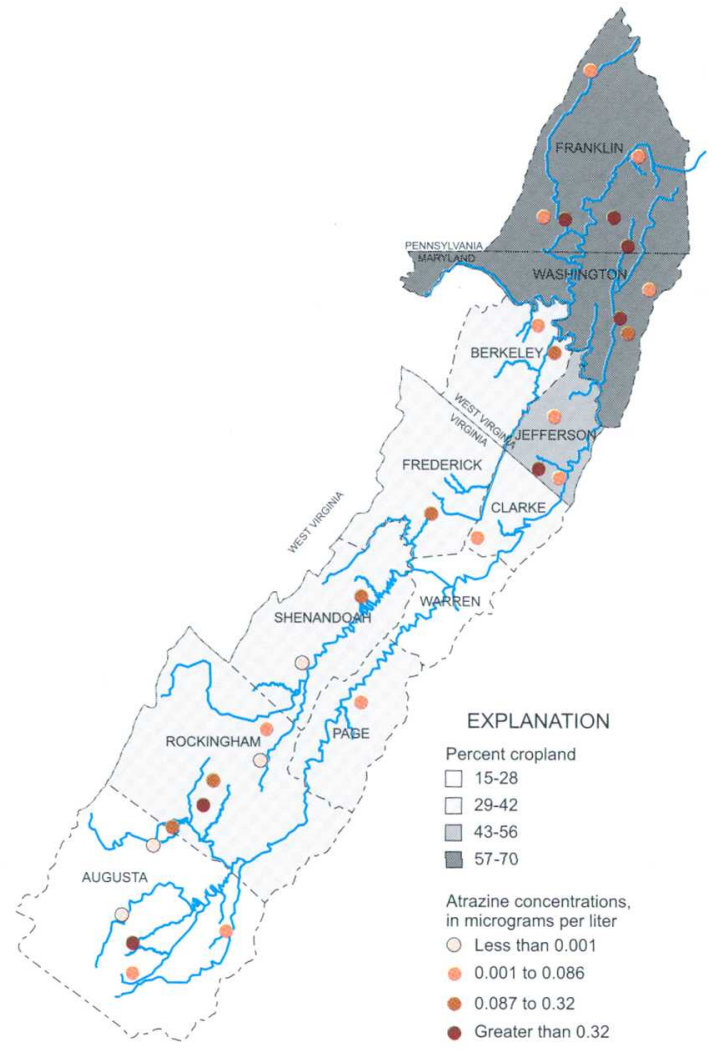

Figure 8. Distribution of atrazine concentrations in ground water from the 1993 Great Valley Carbonate subunit survey and the percentage of land used for crop production in each county.
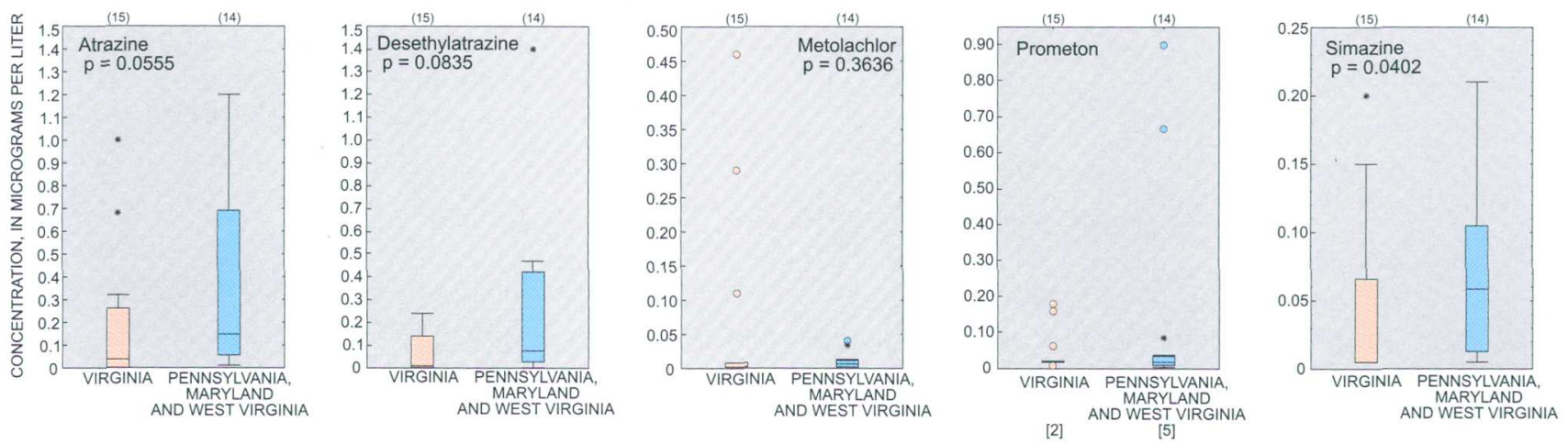

EXPLANATION

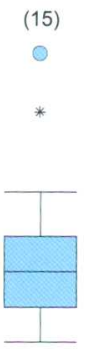

lation to the percentage of cropland. Because the ground-water subunit survey was designed as an agricultural land-use study, cropland and pasture were the predominant land uses (median of cropland plus pasture within half a mile of the wells was equal to 78 percent). Consequently, the ranges in percentages of other land uses around all of the sampling sites were seldom sufficient for the correlation test on their relation to pesticide detection to be valid.

Concentrations of atrazine and metolachlor indicate a significant correlation to the estimated amounts of pesticides used $(\mathrm{p}=0.0011$ for atrazine; $\mathrm{p}=0.0996$ for metolachlor; fig. 10). No significant correlation between estimated use and measured concentrations was seen for simazine $(\mathrm{p}=0.2116$; Spearman's rho= 0.239 ). The lack of a significant correlation for simazine could be due to the limitations in the accuracy of simazine-usage estimates derived from county-level data as described previously in the Methods of Study section.

\section{Small-Scale Variability in Pesticide Occurrence and Concentrations in Ground Water}

A total of 11 compounds were detected at least once in 74 samples collected from 16 wells sampled in the Muddy Creek flow-system study (table 9). Atrazine was the most commonly detected pesticide, found in 80 


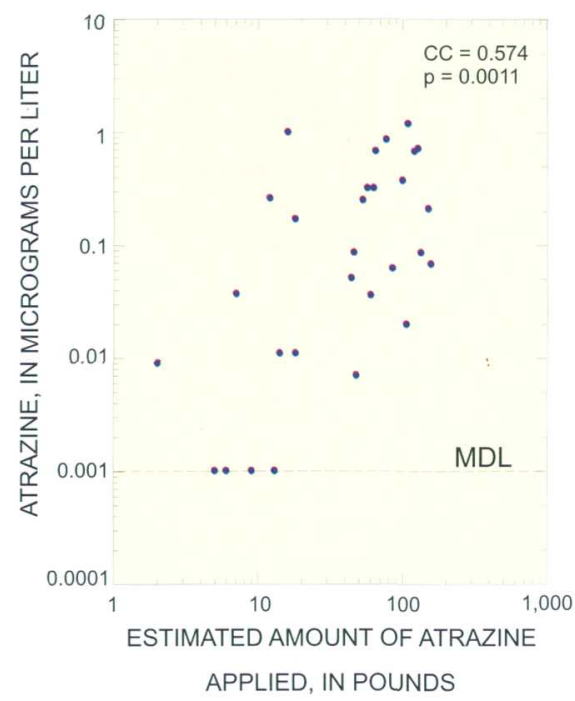

APPLIED, IN POUNDS

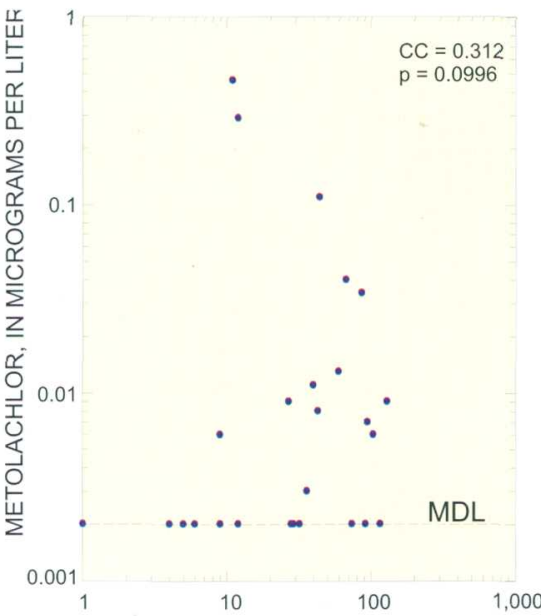

ESTIMATED AMOUNT OF METOLACHLOR

APPLIED, IN POUNDS

EXPLANATION

$\begin{array}{ll}\mathrm{CC}=0.574 & \begin{array}{l}\text { Spearman rank } \\ \text { correlation coefficient }\end{array} \\ \mathrm{p}=0.0011 & \begin{array}{l}\text { Probability of } \\ \text { false correlation }\end{array} \\ \mathrm{MDL} & \text { Method Detection Limit }\end{array}$

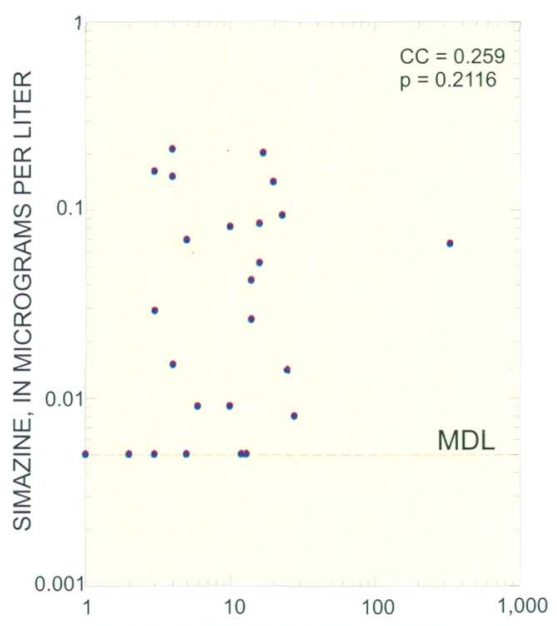

ESTIMATED AMOUNT OF SIMAZINE

APPLIED, IN POUNDS

Figure 10. Relation between measured pesticide concentrations in ground-water samples and estimated amounts applied within half a mile of the wells in the Great Valley Carbonate subunit.

percent of the samples; desethylatrazine, metolachlor, and simazine were detected in more than 50 percent of the samples; prometon was not detected in any of the samples (table 9). Median concentrations of all four compounds were less than $0.1 \mu \mathrm{g} / \mathrm{L}$ (fig. 11); none of the measurable concentrations were greater than the MCLs ( $3 \mu \mathrm{g} / \mathrm{L}$ for atrazine; $4 \mu \mathrm{g} / \mathrm{L}$ for simazine).

Concentrations of atrazine in the wells in the southern part of the study site closest to the stream tended to be fairly low (generally less than $0.1 \mu \mathrm{g} / \mathrm{L}$ ), and most had little temporal variation. Pesticide con-

Table 10. Correlation of concentrations of pesticides in ground water to land-use percentages within half a mile of the wells in the Great Valley Carbonate subunit

\begin{tabular}{lccccc}
\hline & \multicolumn{2}{c}{ Cropland } & & \multicolumn{2}{c}{ Pasture } \\
\cline { 2 - 3 } \cline { 5 - 6 } Compound & rho $^{1}$ & $\begin{array}{c}\text { p- } \\
\text { value }\end{array}$ & & rho $^{1}$ & $\begin{array}{c}\text { p- } \\
\text { value }\end{array}$ \\
\hline Atrazine & 0.543 & 0.0023 & & -0.504 & 0.0054 \\
$\begin{array}{l}\text { Desethlyatra- } \\
\text { zine }\end{array}$ & .605 & .0005 & & -.581 & .0009 \\
$\begin{array}{l}\text { Metolachlor } \\
\text { Simazine }\end{array}$ & .259 & .1751 & & -.353 & .0604 \\
\hline
\end{tabular}

\footnotetext{
${ }^{1}$ Spearman's rho correlation coefficient.
}

${ }^{2}$ Probability of false correlation. centrations also were generally lower in the bedrock wells than in the associated regolith wells. These wells are in a pasture or grass area and are generally the ones farthest from the cropped fields where atrazine was applied. The highest atrazine concentrations were consistently in samples from regolith wells 39S 14 and 39S 16 , located in the central part of the study site and near the cropped fields (fig. 5). Desethylatrazine, metolachlor, and simazine concentrations show similar areal patterns.

\section{Temporal Variability in Pesticide Occurrence and Concentrations in Ground Water}

One objective of the sampling approach used in the Muddy Creek flow-system study is to assess the range and timing of temporal variations in the concentrations of pesticides. Because many of the most widely used pesticides are applied at specific times, samples were collected under different hydrologic conditions and at different times during the year to determine the temporal variability in the concentrations of pesticides in ground water. The maximum variation occurred in well 39S 14, where concentrations ranged from 0.20 to $2.1 \mu \mathrm{g} / \mathrm{L}$, a range extending over an order of magnitude. Other wells showed less temporal variability, mostly from less than the $0.001-\mu \mathrm{g} / \mathrm{L}$ detection level to as high as $0.93 \mu \mathrm{g} / \mathrm{L}$. Peak concentrations of 


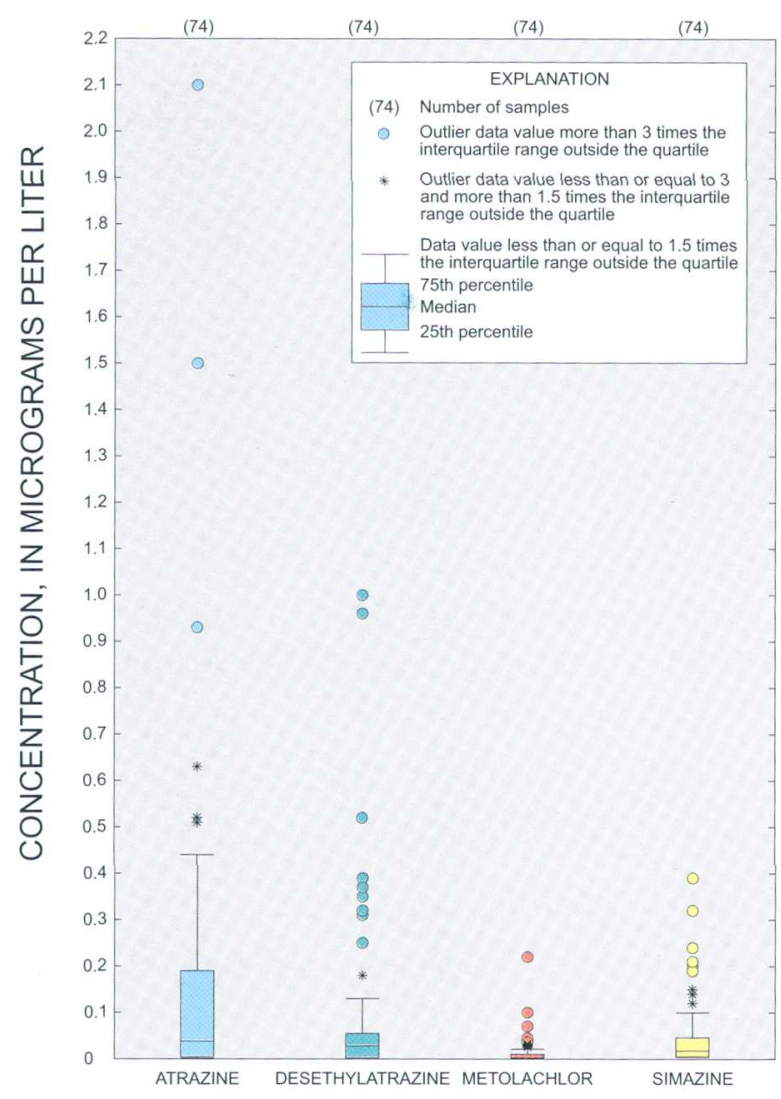

Figure 11. Distributions of concentrations of selected pesticide compounds in ground-water samples from the Muddy Creek flow-system study site.

atrazine were found in the late spring in most wells, but the highest concentration detected was in a sample from well 39S 14 collected in early September. The lowest concentrations of atrazine detected were generally in samples collected during the winter or early spring.

Pesticide concentrations are generally lower in the bedrock wells and the nearby stream than in the associated regolith wells (fig. 12). A comparison of the water levels in wells completed in bedrock and in regolith, however, indicates that ground water generally flows upward from the bedrock towards the regolith. Water samples collected from the stream near well 39S 2 had pesticide concentrations that were generally lower than those in the well. Water levels in the stream adjacent to well 39S 2 indicate that the stream loses water to the regolith throughout most of the year. Although not enough samples were collected and analyzed to derive definitive conclusions about the temporal variability of pesticide concentrations, annual as well as seasonal variations in pesticide concentrations in the regolith could reflect the timing of pesticide application in the spring and frequency of major recharge of water that follows application.

Although seasonal to annual variations in pesticide concentrations are evident in samples from individual wells, these variations can be distinguished only at very local scales. Selected Muddy Creek flow-system wells were sampled in September 1994, March 1995, and June 1995. Although data for individual wells indicate variations in the pesticide concentrations over time, there are no significant differences in the pesticide concentrations among the three flow-system synoptic surveys (fig. 13). Because all of the wells were not sampled during all synoptic surveys, statistical tests were rerun on a subset of the data containing only those wells common to all the surveys. Again, no significant differences were found among the synoptic surveys.

\section{Ground-Water Study-Scale Comparisons}

Except for prometon, pesticides that were commonly detected in samples from the flow-system study and watershed survey were similar to those detected in samples from the subunit survey (table 9). Prometon was not detected in any of the flow-system wells at any time, and was detected in only one of the nine watershed samples. Overall, a greater number of pesticides were detected in samples from the subunit survey than in samples from either the watershed or flow-system study. Therefore, the difference in the number of pesticides detected at the three study scales is probably due to differences in the use of pesticides in the Great Valley as a whole rather than to any differences in use unique to the Muddy Creek area.

A smaller, more local ground-water study generally cannot be substituted for a regional study to determine the occurrence and distribution of pesticides in a regional area. Conversely, regional studies cannot be used to determine local ground-water-quality conditions. Overall, the concentrations of atrazine in the Muddy Creek flow-system samples are significantly different from the atrazine concentrations in the ground-water subunit survey. A Tukey test run on the ranks of atrazine concentrations of the ground-water subunit-survey samples (median $=0.086 \mu \mathrm{g} / \mathrm{L}$ ), the watershed samples $($ median $=0.031 \mu \mathrm{g} / \mathrm{L})$, and the Muddy Creek flow-system samples from June 1995 (median $=0.007 \mu \mathrm{g} / \mathrm{L}$ ), indicates that the subunit-survey and flow-system synoptic sample sets are significantly different (fig. 14). Differences among the sample sets were not detected for the other three 
Well 39S 2 (regolith)
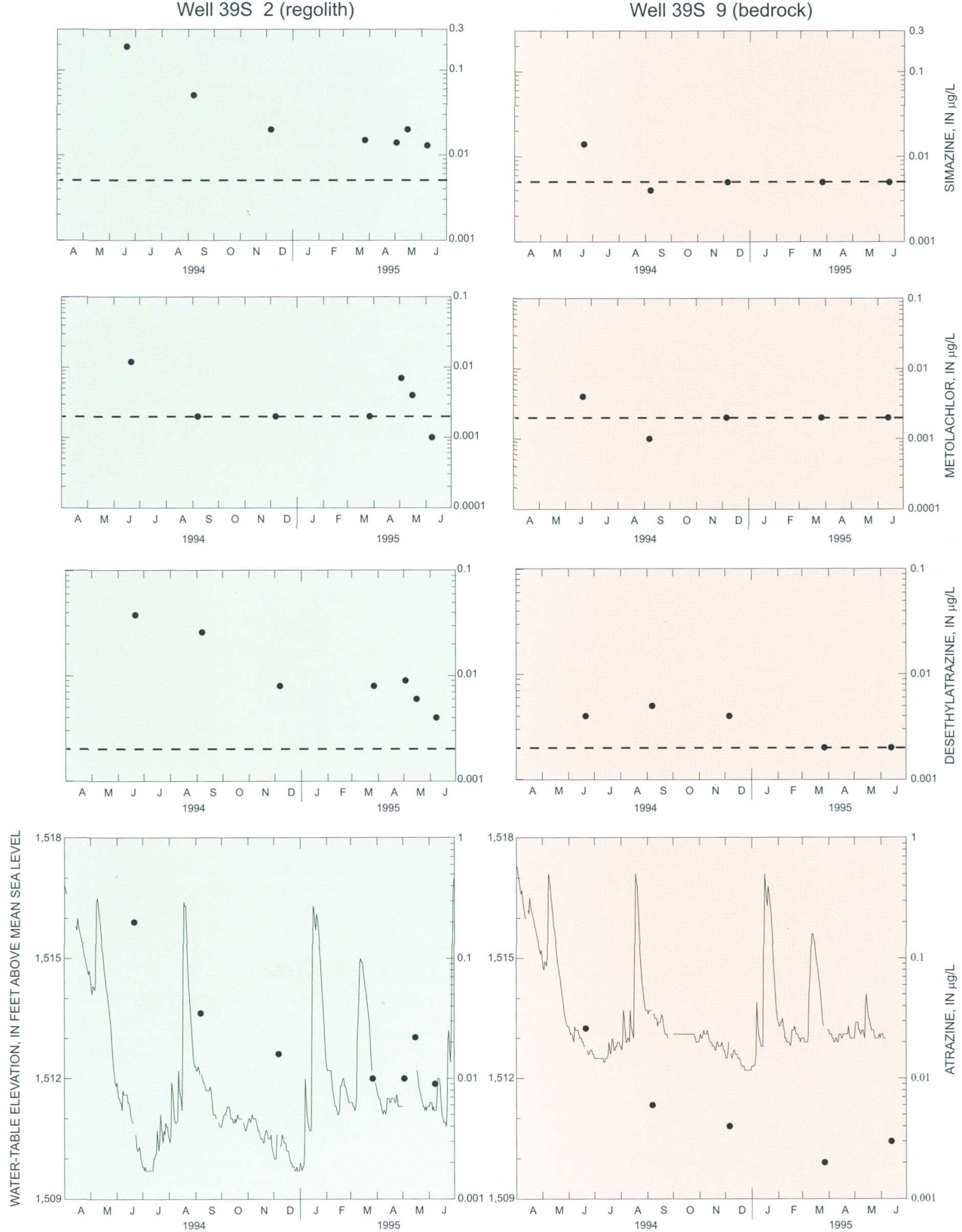

EXPLANATION

Water-table elevation, in feet above mean sea level

Pesticide concentration, in micrograms per liter

Desethylatrazine values are estimated.

- - Method Detection Limit (MDL)

Values below the MDL are estimated.

MDL for atrazine $=0.001 \mu \mathrm{g} / \mathrm{l}$

Figure 12. Comparison of ground-water-level elevations and concentrations of selected pesticide compounds from a well pair at the Muddy Creek flow-system study site. 

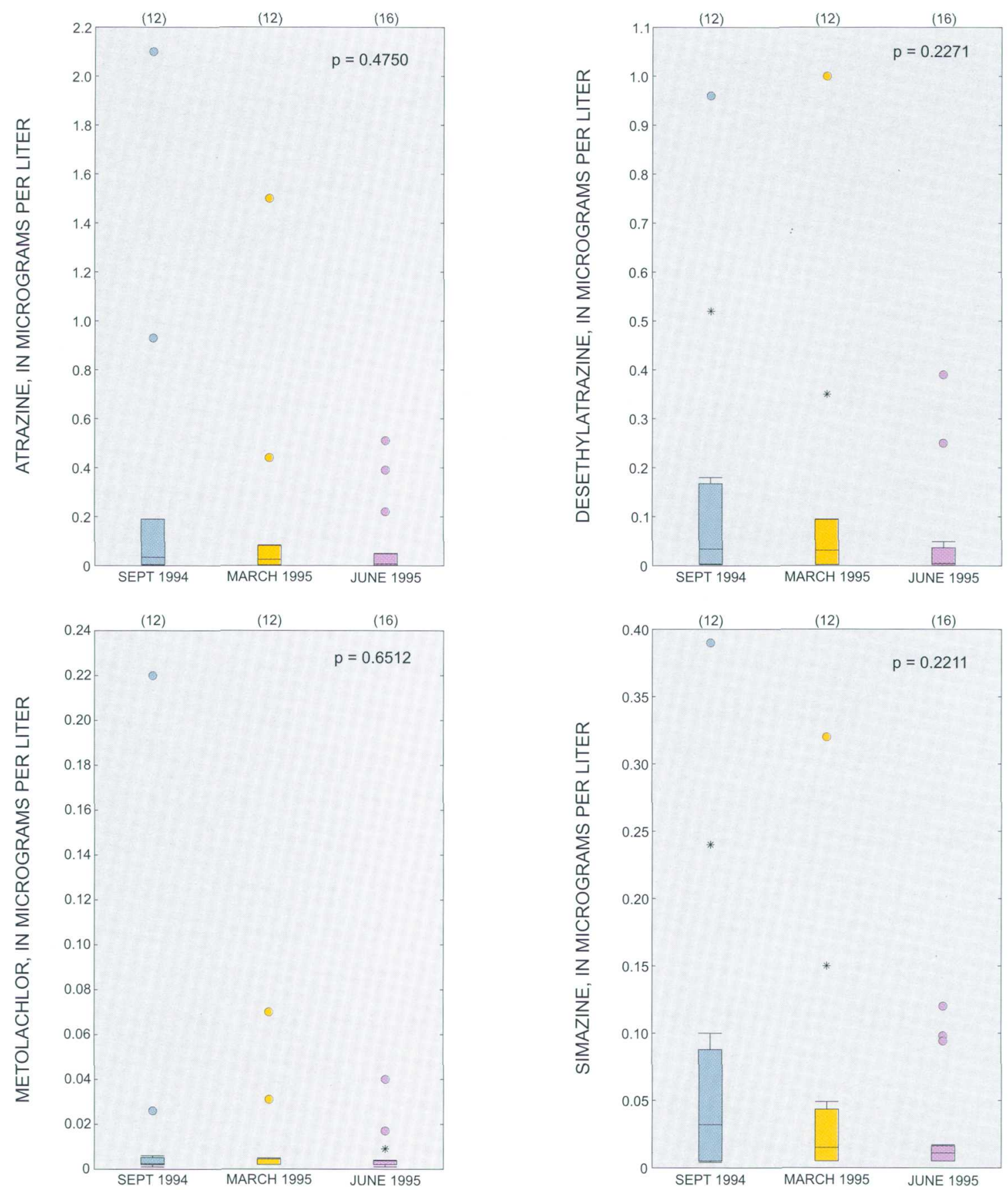

\section{EXPLANATION}
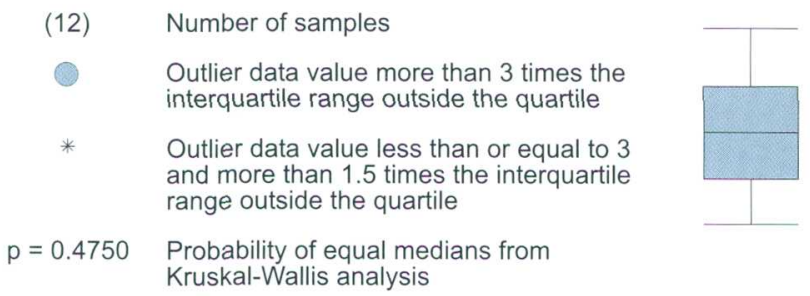

Data value less than or equal to 1.5 times the interquartile range outside the quartile

75th percentile

Median

25th percentile

Figure 13. Distributions of concentrations of selected pesticide compounds in synoptic ground-water samples from the Muddy Creek flow-system study site. 

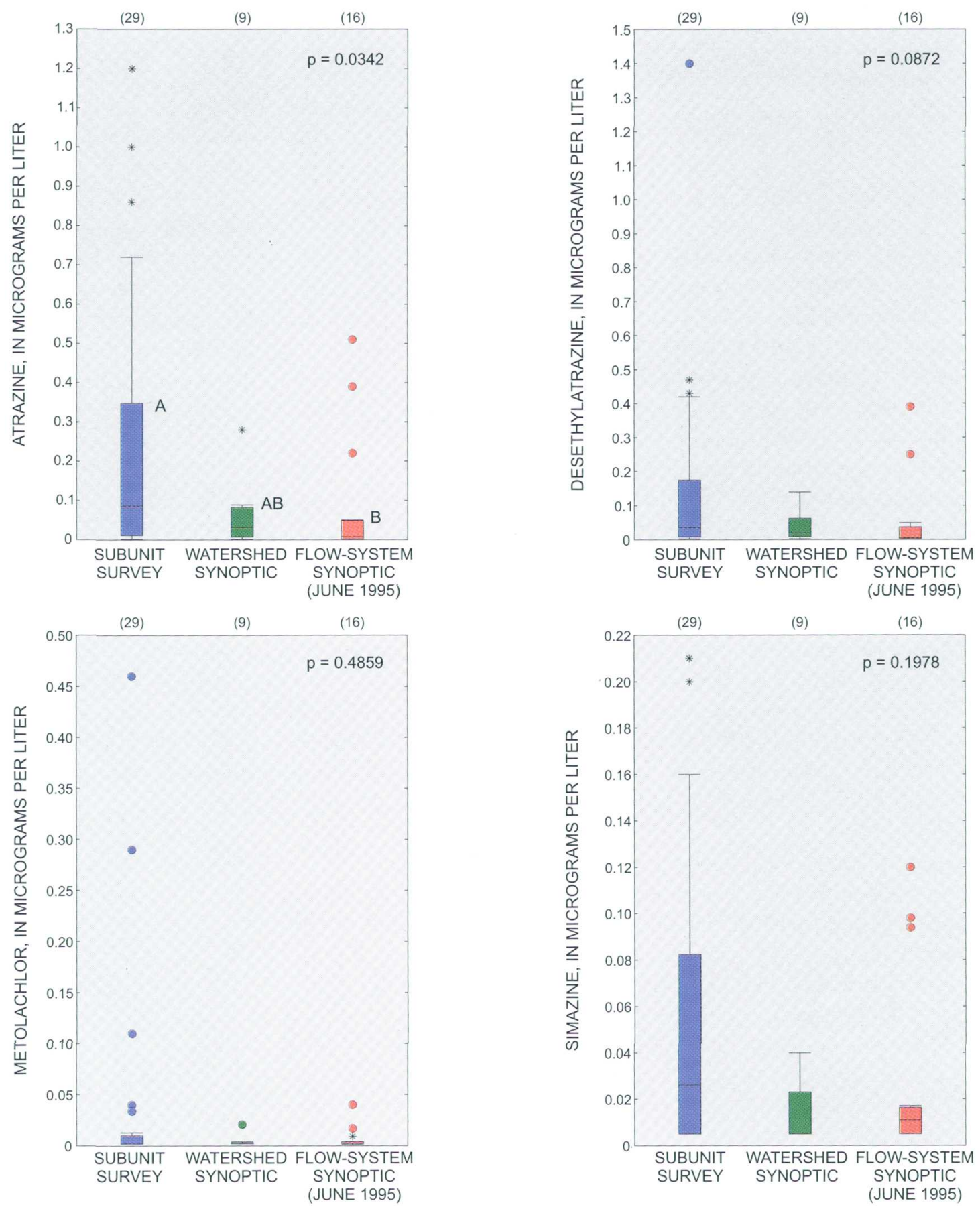

EXPLANATION

(29) Number of samples

- Outlier data value more than 3 times the interquartile range outside the quartile

* Outlier data value less than or equal to 3 and more than 1.5 times the interquartile range outside the quartile

Letters beside boxes indicate results of rank-transform Tukey test (alpha $=0.10$ ) Groups with the same letter are not significantly different

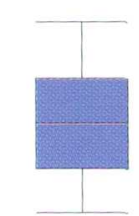

$p=0.0342$ Probability of equal medians from the interquartile range outside the quartile

75th percentile

Median

25th percentile

\section{$p=0.0342 \quad \begin{aligned} & \text { Probability of equal med } \\ & \text { Kruskal-Wallis analysis }\end{aligned}$}

Data value less than or equal to 1.5 times

Figure 14. Distributions of concentrations of selected pesticide compounds in ground-water samples at three different study scales in the Great Valley Carbonate subunit. 
compounds. For each of the compounds, samples from the ground-water subunit survey had the greatest overall range of concentrations and the largest interquartile (25th to 75 th percentile) range.

\section{Pesticides in Surface Water}

All of the streams sampled in the Great Valley for the subunit synoptic survey contained detectable levels of multiple pesticides (fig. 15; table 11). All of the samples contained detectable concentrations of at least 5 compounds, with 6 of the samples containing detectable concentrations of up to 15 compounds. A recent study of endocrine disrupters examined the possible link between the occurrence of multiple contaminants in the environment and adverse health effects in fish (Goodbred and others, 1997), but the results were inconclusive.

Atrazine, desethylatrazine, metolachlor, and simazine were each detected in all surface-water samples, and prometon was detected in 96 percent of samples. Tebuthiuron was detected in 48 percent of the samples. In addition, 17 other pesticide compounds were detected in fewer than 25 percent of the subunitsynoptic samples (table 9). None of the measured concentrations of pesticides was greater than any established MCLs.

Some of the pesticides were detected in surface water throughout the Great Valley Carbonate subunit with the highest concentrations occurring predominantly in the north. For example, concentrations of atrazine in surface water exhibit a general north-south variation (fig. 16), which is similar to that found for concentrations of atrazine in ground water (fig. 8). Atrazine concentrations in surface-water samples from Pennsylvania, Maryland, and West Virginia, where the land is used primarily for crop production, had a median of $0.23 \mu \mathrm{g} / \mathrm{L}$. Samples from Virginia, where land use is primarily pasture, had a median of $0.075 \mu \mathrm{g} /$ L. On the basis of a rank sum test, atrazine concentrations in surface-water samples from the northern States of the Great Valley Carbonate subunit were found to be significantly different ( $\mathrm{p}=0.0003)$, and in this case, higher than atrazine concentrations in Virginia (fig. 17). This north-south variation in concentrations of pesticide compounds also appears to be significant for

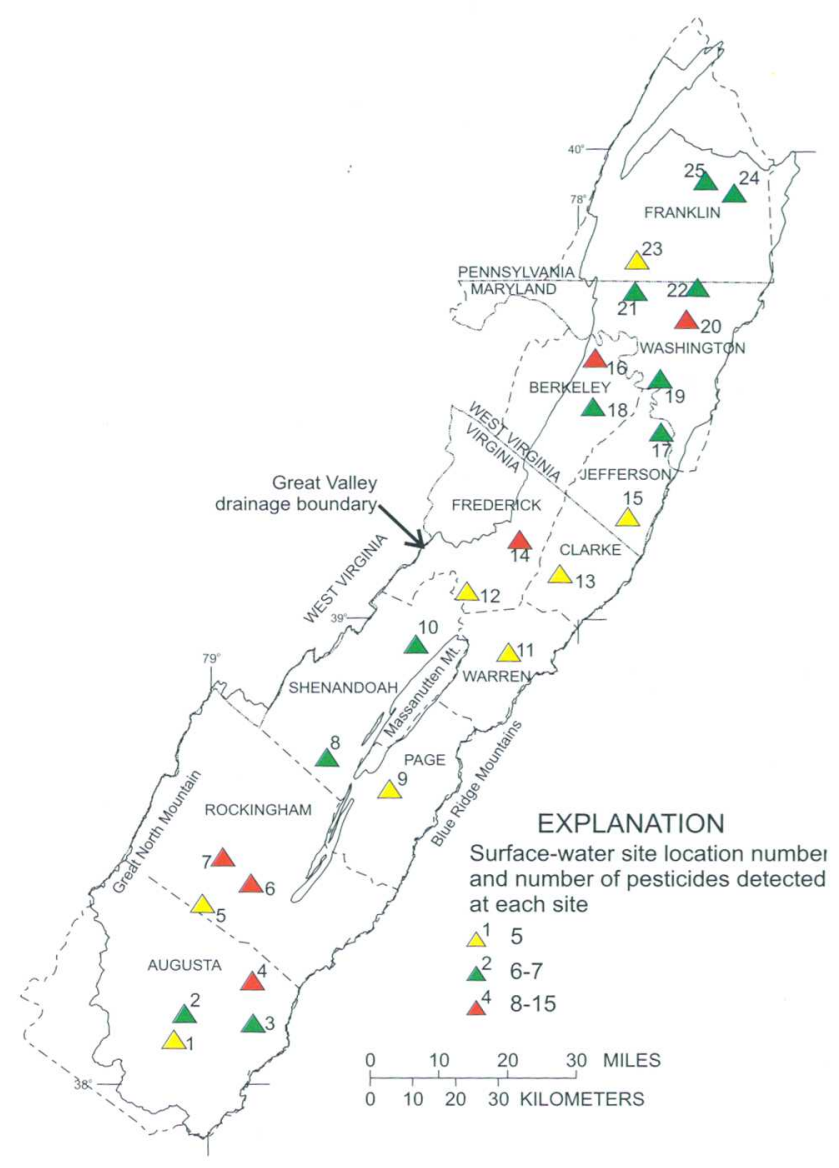

Figure 15. Number of pesticide compounds detected at each surface-water subunit synoptic survey sampling location in the Great Valley.

desethylatrazine, metolachlor, and simazine concentrations $(\mathrm{p}=0.0001, \mathrm{p}=0.0066$, and $\mathrm{p}=0.0193$, respectively). Differences in spatial distribution could not be determined for prometon because of values reported below the MDL. 
Table 11. Selected physical characteristics and concentrations of selected pesticides detected at 25 surface-water sites under base-flow conditions in the Great Valley Carbonate subunit, September 1993

$\left[\mathrm{mi}^{2}\right.$, square mile; $\mathrm{ft}^{3} / \mathrm{s}$, cubic feet per second; $\mu \mathrm{g} / \mathrm{L}$, micrograms per liter; E, estimated; <, less than]

\begin{tabular}{|c|c|c|c|c|c|c|c|c|c|}
\hline \multirow[b]{2}{*}{$\begin{array}{l}\text { Site } \\
\text { no. }\end{array}$} & \multirow[b]{2}{*}{ Site name } & \multirow[b]{2}{*}{$\begin{array}{l}\text { Dominant } \\
\text { land use }{ }^{1}\end{array}$} & \multirow[b]{2}{*}{$\begin{array}{l}\text { Drainage } \\
\text { area }\left(\mathbf{m i}^{2}\right)\end{array}$} & \multirow[b]{2}{*}{$\begin{array}{l}\text { Measured } \\
\text { stream- } \\
\text { flow } \\
\left(\mathrm{ft}^{3} / \mathbf{s}\right)\end{array}$} & \multicolumn{5}{|c|}{ Compound $(\mu g / L)$} \\
\hline & & & & & $\begin{array}{l}\text { Atra- } \\
\text { zine }\end{array}$ & $\begin{array}{l}\text { Des- } \\
\text { ethyl- } \\
\text { atra- } \\
\text { zine }\end{array}$ & $\begin{array}{l}\text { Meto- } \\
\text { lachlor }\end{array}$ & $\begin{array}{l}\text { Pro- } \\
\text { meton }\end{array}$ & $\begin{array}{c}\text { Sima- } \\
\text { zine }\end{array}$ \\
\hline 1 & Folly Mills Creek near Staunton, Va. & Pasture & 15.0 & 4.5 & 0.042 & E 0.017 & 0.002 & E 0.008 & 0.005 \\
\hline 2 & Lewis Creek at Staunton, Va. & Urban & 15.0 & 7.0 & .024 & E .005 & .012 & .077 & .005 \\
\hline 3 & Porterfield Run near Crimora, Va. & Pasture & 4.42 & .31 & .13 & E .077 & .005 & E .007 & .03 \\
\hline 4 & Polecat Draft near Piedmont, Va. & Pasture & 5.61 & .52 & .093 & E .047 & .002 & E .006 & .016 \\
\hline$\dot{5}$ & Mossy Creek near Spring Creek, Va. & Pasture & 15.3 & 16. & .012 & E $\quad .008$ & .003 & $<.018$ & .005 \\
\hline 6 & Blacks Run at Harrisonburg, Va. & Urban & 5.26 & 1.1 & .28 & E .010 & 1.7 & .51 & .15 \\
\hline 7 & Muddy Creek at Mount Clinton, Va. & Pasture & 14.2 & 1.9 & .079 & E .054 & .005 & E .012 & .021 \\
\hline 8 & Holmans Run at Quicksburg, Va. & Pasture & 17.9 & 3.9 & .030 & E .009 & .17 & E .012 & .022 \\
\hline 9 & Mill Creek near Hamburg, Va. & Pasture & 8.11 & .81 & .077 & E .044 & .002 & E .012 & .032 \\
\hline 10 & Toms Brook at Toms Brook, Va. & Forest & 9.48 & .98 & .046 & E .036 & .002 & .035 & .010 \\
\hline 11 & Happy Creek at Crosby Stadium at Front Royal, Va. & Forest & 15.2 & .13 & .008 & E .004 & .006 & .21 & .017 \\
\hline 12 & Buffalo Marsh Run near Middletown, Va. & Pasture & 6.8 & 2.2 & .081 & E .072 & .002 & .020 & .043 \\
\hline 13 & Page Brook at Boyce, Va. & Pasture & 4.89 & .58 & .074 & E .021 & .002 & .059 & .018 \\
\hline 14 & Town Run at Winchester, Va. & Urban & 3.58 & 1.5 & .091 & E .036 & .40 & .18 & .036 \\
\hline 15 & Bullskin Run above Kabletown, W. Va. & Cropland & 19.1 & 8.3 & .23 & E .18 & .11 & .037 & .044 \\
\hline 16 & Harlan Run near Spring Mills, W. Va. & Cropland & 12.2 & 5.8 & .089 & E .10 & .014 & .019 & .019 \\
\hline 17 & Rattlesnake Run near Sheperdstown, W. Va. & Cropland & 8.43 & 1.3 & .27 & E .23 & .022 & .044 & .048 \\
\hline 18 & Tuscarora Creek at Martinsburg, W. Va. & Forest & 20.0 & 8.4 & .065 & E .045 & .22 & .039 & .017 \\
\hline 19 & Marsh Run at Grimes, Md. & Cropland & 18.7 & 3.2 & .21 & E .12 & .043 & .064 & .024 \\
\hline 20 & Hamilton Creek at Hagerstown, Md. & Urban & 5.21 & 2.4 & .19 & E .072 & 1.9 & .17 & .030 \\
\hline 21 & Rockdale Run at Fairview, Md. & Cropland & 9.65 & 4.7 & .20 & E .18 & .029 & .029 & .030 \\
\hline 22 & Marsh Run at Reid, Md. & Cropland & 16.8 & 3.8 & .43 & E .24 & .015 & .044 & .082 \\
\hline 23 & Welsh Run at Welsh Run, Pa. & Cropland & 3.59 & .94 & .23 & E .24 & .010 & .018 & .062 \\
\hline 24 & Conococheague Creek Tributary at Fayetteville, $\mathrm{Pa}$. & Cropland & 9.24 & .37 & .73 & E .69 & .089 & .077 & .096 \\
\hline 25 & Falling Spring at Chambersburg, Pa. & Cropland & 9.35 & 33. & .36 & E .21 & .041 & .052 & .053 \\
\hline
\end{tabular}

${ }^{1}$ Agricultural land use is divided into cropland and pasture classifications. 


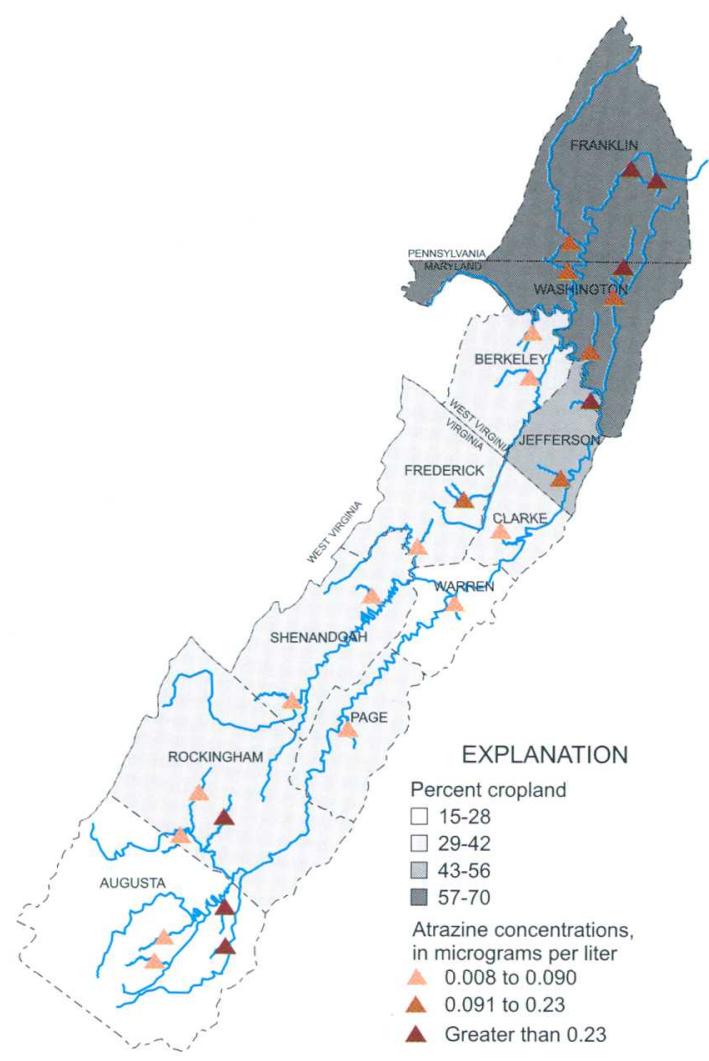

Figure 16. Distribution of atrazine concentrations in surface water from the 1993 Great Valley Carbonate subunit synoptic survey and the percentage of land used for crop production in each county.
Concentrations of atrazine, desethylatrazine, and simazine have a significant positive correlation to the percentage of cropland within the contributing watersheds (table 12). Atrazine concentrations have a significant negative correlation to the percentage of pasture because an increase in land used for pasture reduces the land available for corn production, thus reducing atrazine applications. Metolachlor indicates no significant correlation to the percentage of cropland within the contributing watersheds, but did indicate a positive correlation with urban land use.

Atrazine concentrations in stream samples indicate a significant correlation to the estimated amounts used ( $\mathrm{p}=0.0004$; Spearman's rho=0.658) (fig. 18). No significant correlation was seen for either metolachlor $(\mathrm{p}=0.3911$; Spearman's rho $=0.179)$ or simazine $(\mathrm{p}=$ 0.4677; Spearman's rho=-0.152). Sampling the first flush of pesticides shortly after pesticide application may improve correlations of pesticide concentrations to the amounts of pesticide applied. Results from the subunitsynoptic sampling approach indicate that measurable concentrations of agricultural pesticides are still detectable at base-flow conditions in September, long after pesticide application in the spring.
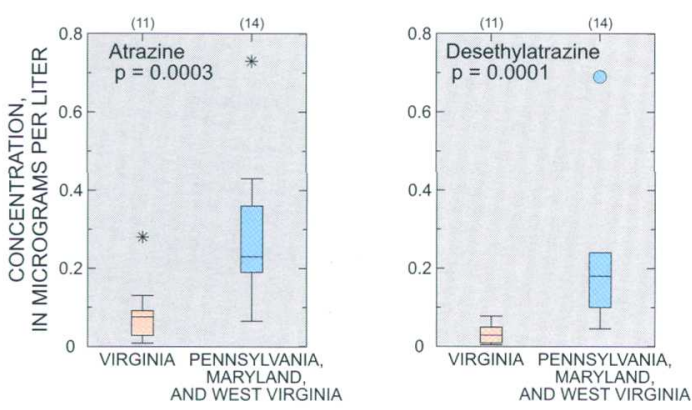

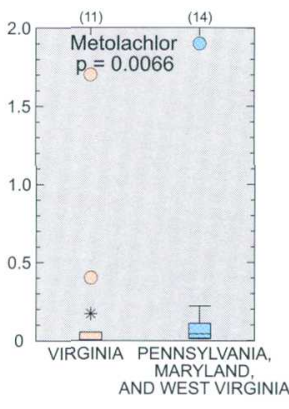

EXPLANATION
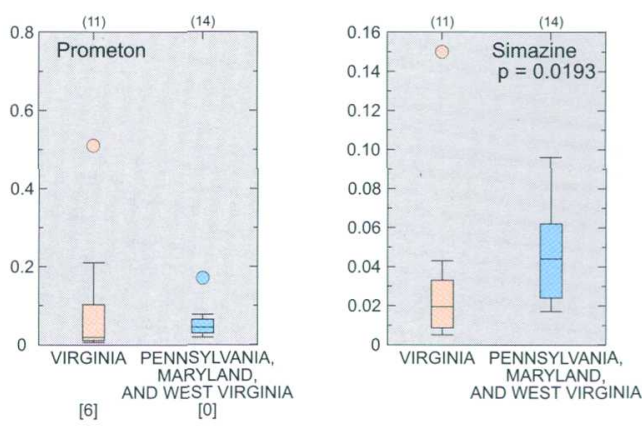

(11) Number of samples
Outlier data value more than 3 times the interquartile
range outside the quartile
Outlier data value less than or equal to 3 and more than
1.5 times the interquartile range outside the quartile
Data value less than or equal to 1.5 times the
interquartile range outside the quartile
75th percentile
Median
25th percentile

$p=0.0003$ Probability of equal medians from rank sum analysis

Note for Prometon:

p-values not calculated for prometon because of values reported below the MDL (Method Detection Limit). Number in brackets is the number of concentrations reported below the MDL.

Figure 17. Distributions of concentrations of pesticide compounds in surface water from the 1993 Great Valley Carbonate subunit synoptic survey by geographic region. 
Table 12. Correlation of concentrations of pesticides in surface water to land-use percentages in contributing watersheds in the Great Valley Carbonate subunit

\begin{tabular}{|c|c|c|c|c|c|c|}
\hline \multirow{2}{*}{ Compound } & \multicolumn{2}{|c|}{ Cropland } & \multicolumn{2}{|c|}{ Pasture } & \multicolumn{2}{|c|}{ Urban } \\
\hline & rho $^{1}$ & $p$-value ${ }^{2}$ & rho $^{1}$ & p-value ${ }^{2}$ & rho $^{1}$ & $p$-value ${ }^{2}$ \\
\hline Atrazine & 0.665 & 0.0003 & -0.486 & 0.0137 & -0.0915 & 0.6634 \\
\hline Desethylatrazine & .853 & .0001 & -.396 & .0502 & -.385 & .0576 \\
\hline Metolachlor & .0972 & .6439 & -.715 & .0001 & .438 & .0284 \\
\hline Simazine & .464 & .0196 & -.439 & .0280 & .0316 & .8806 \\
\hline
\end{tabular}

${ }^{1}$ Spearman's rho correlation coefficient.

${ }^{2}$ Probability of false correlation.
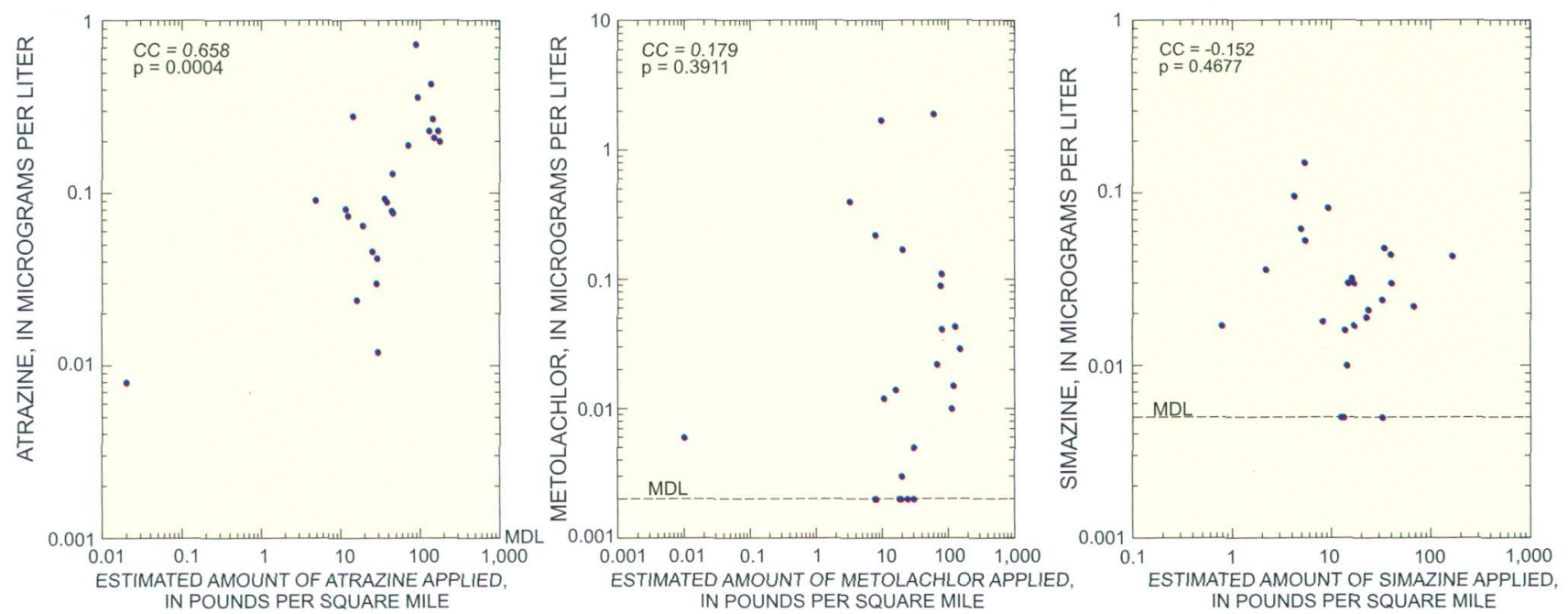

$$
\begin{array}{cl}
\multicolumn{2}{c}{\text { EXPLANATION }} \\
\mathrm{CC}=0.658 & \begin{array}{l}
\text { Spearman rank } \\
\text { correlation coefficient }
\end{array} \\
\mathrm{p}=0.0004 & \begin{array}{l}
\text { Probability of } \\
\text { false correlation }
\end{array} \\
\text { MDL } & \text { Method Detection Limit }
\end{array}
$$

Figure 18. Relation between measured pesticide concentrations in stream samples and estimated amounts applied per square mile within the contributing basins, Great Valley Carbonate subunit. 
Temporal Variability of Pesticides in Surface Water

Seasonal patterns in the occurrence and concentration of selected pesticides can be observed in the Great Valley Carbonate subunit. Peak concentrations of pesticides are detected during the spring application period, generally between April and June (Roeser, 1988), and during the growing season, from July through September (fig. 19). Rainfall and consequent runoff following pesticide application typically result in the transport of high concentrations of pesticides to streams (U.S. Geological Survey, 1997).

In general, commonly detected agricultural pesticides appear to have their highest concentrations in surface water soon after application, which typically occurs in the spring to early summer of each year. Maximum concentrations of atrazine, simazine, metolachlor, and desethylatrazine were detected in May at both fixed sites. Concentrations of atrazine at Muddy Creek were above the MCL of $3 \mu \mathrm{g} / \mathrm{L}$ in two water samples collected immediately following spring runoff events. Concentrations of atrazine in subsequent samples a week later were below the MCL. Concentrations of simazine at Muddy Creek above the MCL of $4 \mu \mathrm{g} / \mathrm{L}$ were only found in a single water sample collected after a spring runoff event. Concentrations of atrazine and simazine in all water samples from Shenandoah River at Millville, W. Va., were below their respective MCLs. The highest concentration of prometon occurred in July in the Shenandoah River. No detections of prometon were above the MDL at Muddy Creek at Mount Clinton, Va.

Desethylatrazine was detected throughout the year at the Muddy Creek and Shenandoah River sites. The distribution of desethylatrazine concentrations at Muddy Creek was between $0.024 \mu \mathrm{g} / \mathrm{L}$ and $0.098 \mu \mathrm{g} / \mathrm{L}$ for most of the sampling period except during the spring application period in 1993, when concentrations were generally higher. The constant range of desethylatrazine concentrations in Muddy Creek throughout the sampling period indicates that ground water, which represented about 72.5 percent of the flow in 1994, provided a constant source of desethylatrazine to the creek. In contrast, the concentrations of desethylatrazine in the Shenandoah River were below $0.01 \mu \mathrm{g} / \mathrm{L}$ at various times of the year. In 1994, base flow contributed about 54.4 percent of the total flow of the Shenandoah River at Millville, W. Va. The Shenandoah River flows from the south and drains much forested land on the mountains. Base flow from the mountains, which are underlain by crystalline rock, is much more vari- able (high in the spring and low in the summer) than base flow from the valley, which is underlain by carbonate rock.

Frequent sampling increases the likelihood of detecting measurable concentrations of pesticides. Seasonal patterns were better defined in 1993, when water samples were collected about once a week at Muddy Creek and from one to two times a month at Shenandoah River. Seasonal patterns were less defined in 1994, when water samples were collected about once a month at Muddy Creek and about every other month until June and July at the Shenandoah River site.

\section{Surface-Water Study-Scale Comparisons}

The occurrence and variability of pesticides at two fixed sites in the Great Valley are dependent upon scale. Nineteen different pesticide compounds were detected at Muddy Creek, a small agricultural watershed ( 73 percent agricultural, 22 percent forest, 5 percent urban), whereas only 10 different compounds were detected at Shenandoah River (table 9), a large watershed that contains a mixture of land uses (51 percent forest, 40 percent agricultural, 7 percent urban). Fewer detections of different pesticides in the larger watershed may be due in part to the dilution of pesticides, especially the dilution of lesser-used pesticides to below detectable levels. Other factors affecting the number of compounds detected include the extent of pesticide use throughout the year and the sampling frequency at each fixed site.

Throughout the period of sampling at Muddy Creek and Shenandoah River (table 3), concentrations of atrazine, simazine, metolachlor, prometon, and desethylatrazine were detected at low levels (generally less than $1 \mu \mathrm{g} / \mathrm{L}$ ). Median concentrations of atrazine at both fixed sites were not significantly different, but the median concentration of desethylatrazine was significantly higher $(\mathrm{p}=0.0001)$ at Muddy Creek. The median concentrations for metolachlor, prometon, and simazine were significantly higher at Shenandoah River $(\mathrm{p}=0.0001, \mathrm{p}=0.0001, \mathrm{p}=0.0801$, respectively; fig. 20). Therefore, the use of atrazine, simazine, metolachlor, and prometon may be more extensive in the Shenandoah River watershed than in the small Muddy Creek watershed. 
Muddy Creek at Mount Clinton, Va.
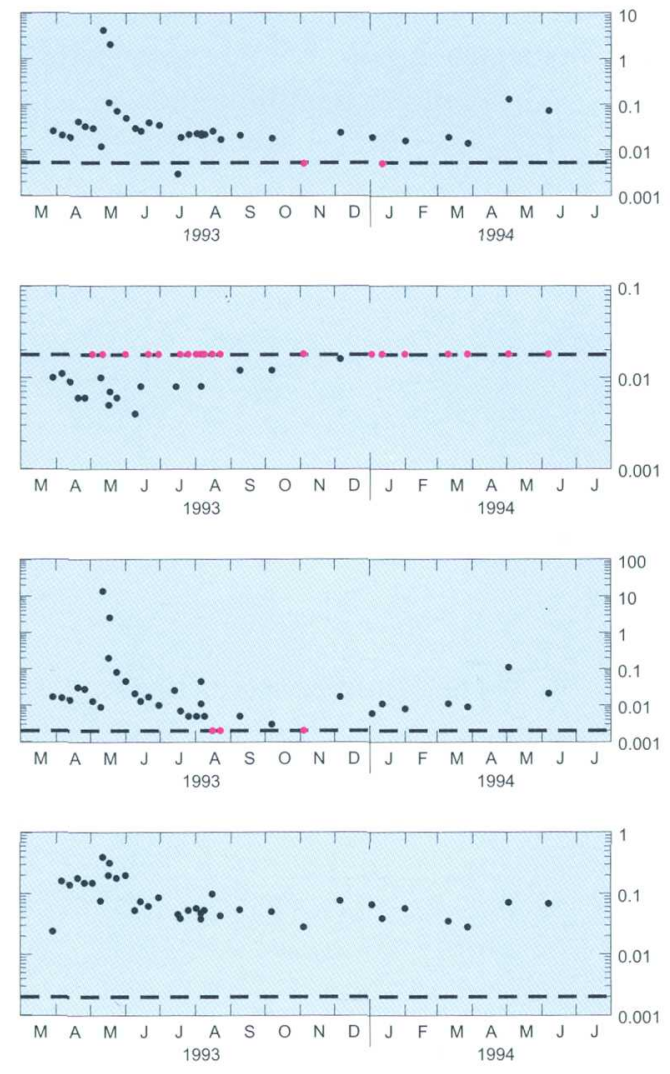

Shenandoah River at Millville, W. Va.
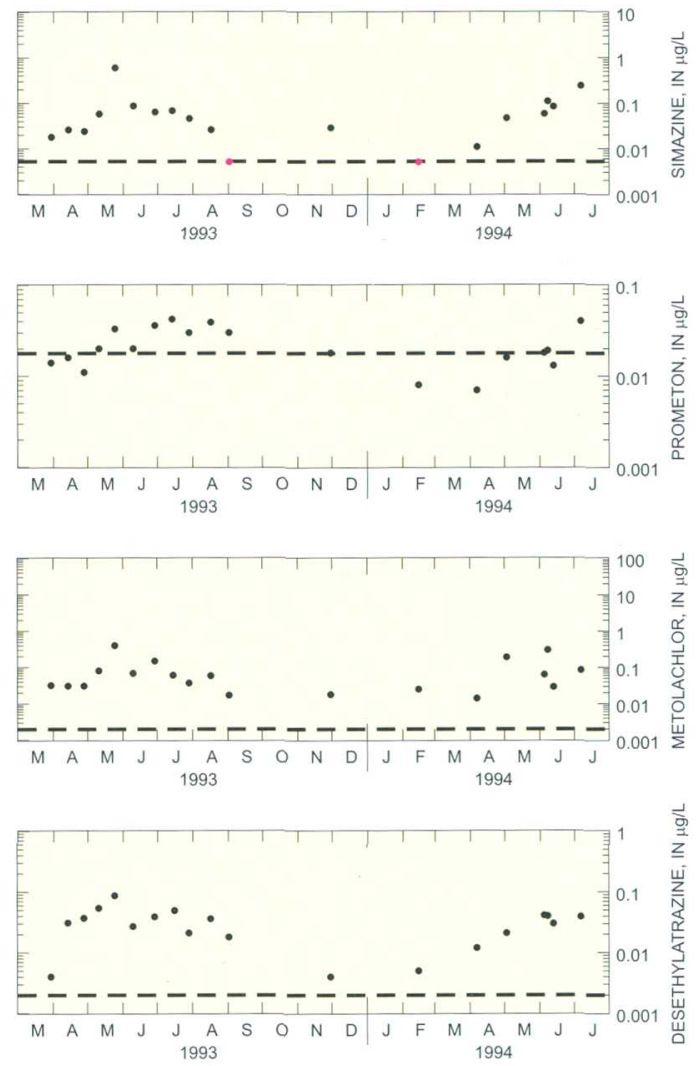
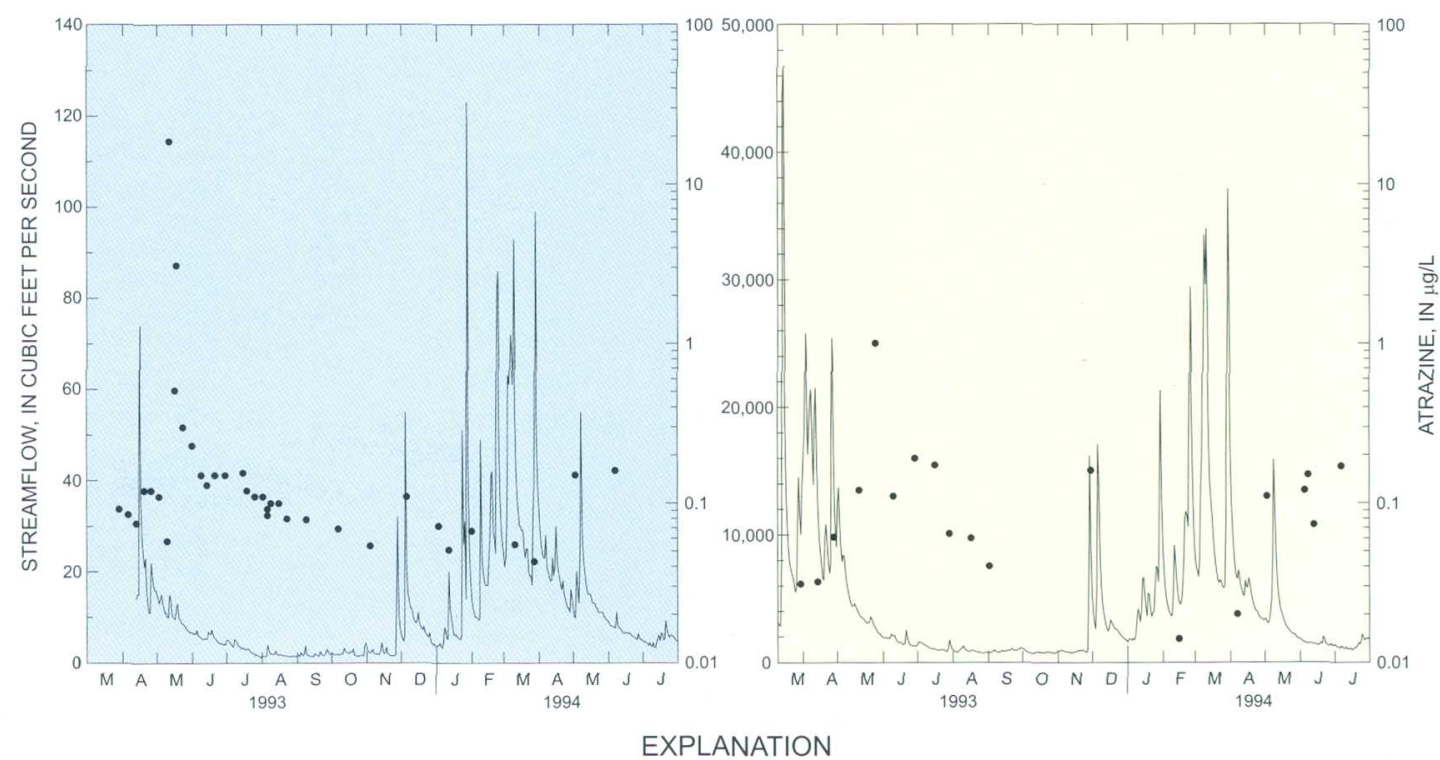

\section{EXPLANATION}

Streamflow, in cubic feet per second

Pesticide concentration, in micrograms per liter Desethylatrazine concentrations are estimated

Pesticide concentration reported as not detected at the Method Detection Limit (MDL)

- - Method Detection Limit (MDL)

Values below the MDL are estimated. MDL for atrazine $=0.001 \mu \mathrm{g} / \mathrm{L}$

Figure 19. Streamflow and pesticide concentrations for two fixed sites in the Great Valley. 


\section{RELATION OF PESTICIDES IN GROUND WATER TO PESTICIDES IN SURFACE WATER}

Subunit-survey and subunit-synoptic-survey sampling approaches were designed to facilitate comparisons between ground water and surface water in the Great Valley Carbonate subunit. Measured pesticide concentrations and flow in ground water were compared to those in surface water within the Muddy Creek watershed.

\section{Regional Similarities and Differences}

Land use within each subunit sampling network was representative of cropland and pasture land throughout the Great Valley Carbonate subunit.

Although the wells sampled for the ground-water subunit survey were selected, in part, because of their proximity to agricultural land, and the watersheds sam- pled for the surface-water subunit synoptic survey were selected to represent all of the major land uses in the Great Valley, land use within half a mile of the wells was similar to the land use within the watersheds. Differences in the medians of either percent cropland (ground-water subunit survey $=41.7$ percent; surfacewater subunit synoptic survey $=31.5$ percent; $\mathrm{p}=$ 0.6135 ) or percent pasture (ground-water subunit survey $=24.9$ percent; surface-water subunit synoptic survey $=19.4$ percent; $p=0.6750$ ) were not significant.

Atrazine, desethylatrazine, metolachlor, prometon, and simazine were detected more frequently in surface water than in ground water at the subunit scale (table 9). No significant differences in the median concentrations of atrazine, desethylatrazine, and simazine in ground-water and surface-water samples were detected (fig. 21); however, a significant difference in the median concentration of metolachlor in ground water and surface water was detected $(\mathrm{p}=0.0016)$. For atrazine, desethylatrazine, and simazine, the maximum concentrations were detected in ground water; how-
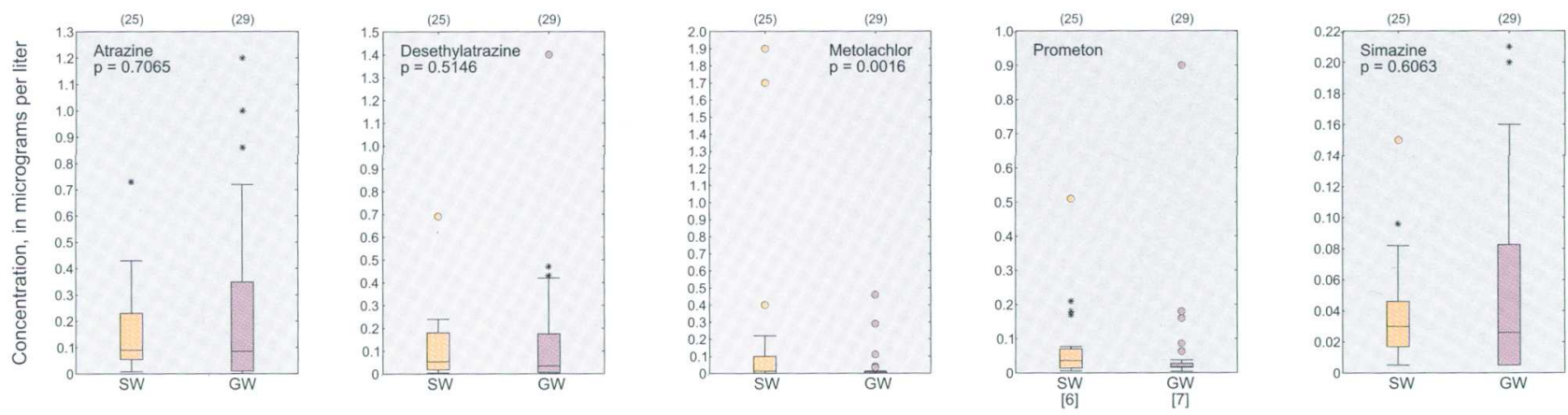

EXPLANATION
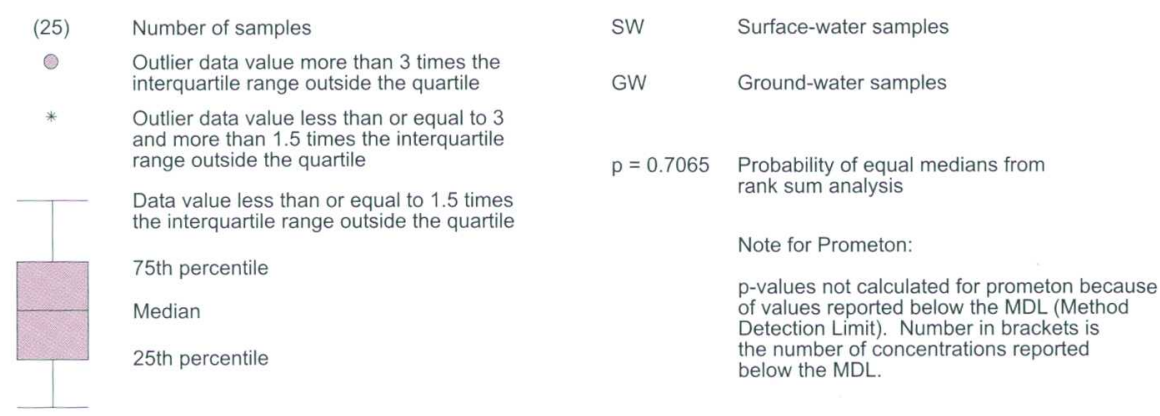

Figure 21. Pesticide concentrations in ground water and surface water in the Great Valley Carbonate subunit, 1993. 


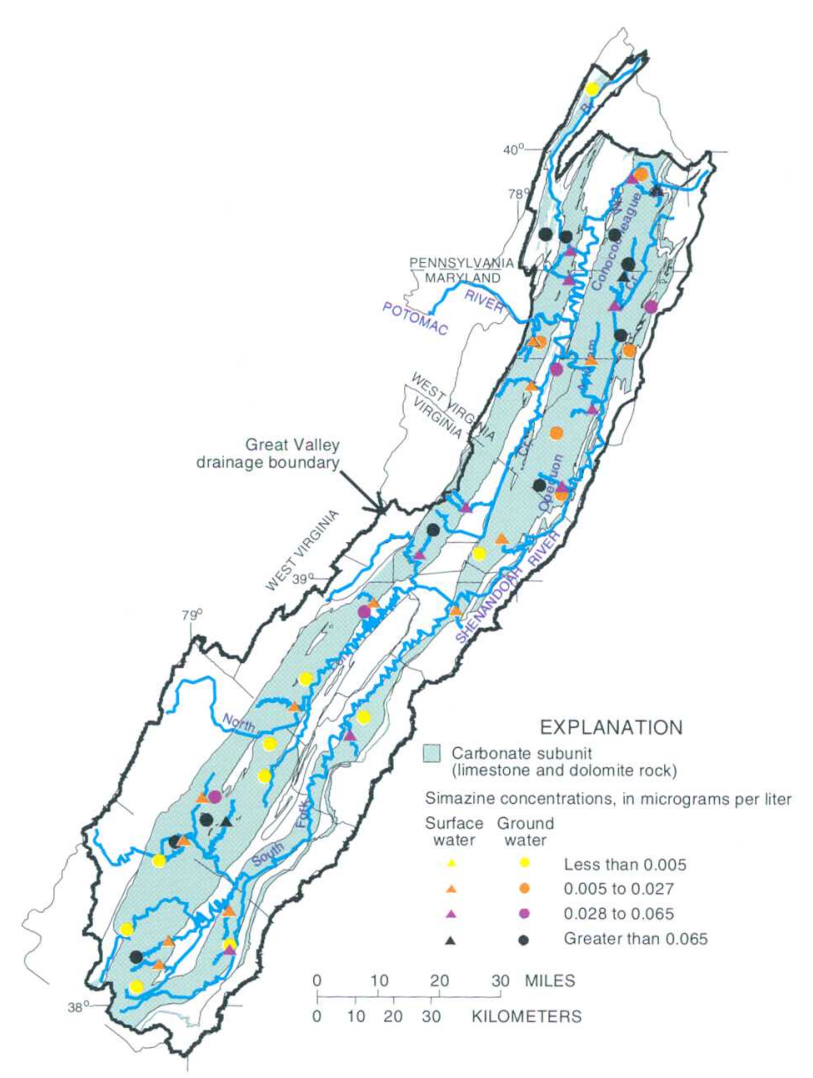

Figure 22. Concentrations of simazine in ground water and surface water in the Great Valley Carbonate subunit, 1993.

ever, these concentrations were found in samples collected in June during pesticide application. For metolachlor, the maximum concentration was detected in surface water. The differences in concentrations between metolachlor and the other pesticides may be due to the differences in the physical properties of these compounds. Atrazine and simazine are both triazines, with similar solubilities ( 33 and 3.5 parts per million at 20 degrees Celsius, respectively; Meister Publishing Company, 1997) and environmental persistence (moderately persistent to persistent, for both; Briggs, 1992), whereas metolachlor is an amide, which has a higher solubility (530 parts per million; Meister Publishing Company, 1997) and a lower persistence (non-persistent; Briggs, 1992).

In a carbonate setting, where ground water and surface water are hydraulically well connected, the differences in the sampling period may play a role in the differences in distribution of measured concentrations of pesticide compounds in ground-water and surfacewater samples from the subunit-scale studies. Temporal differences cannot be explained using these sampling networks; however, the flow-system and fixed- site networks may provide inferences about seasonality and place the data collected for subunit studies into a seasonal context.

Atrazine, desethylatrazine, metolachlor, prometon, and simazine are commonly detected in ground water and surface water throughout the Great Valley Carbonate subunit, but there is a distinct geographical distribution of agricultural pesticides detected in this subunit. Atrazine and simazine are used primarily on corn. The concentrations of simazine in water samples indicate a geographic distribution similar to that of atrazine (fig. 22). A significant difference ( $p=0.0063$ ) was seen between the simazine concentrations in samples from the northern part of the Great Valley Carbonate subunit (median $=0.048 \mu \mathrm{g} / \mathrm{L}$ ) and the concentrations in samples from the southern part (median= $0.017 \mu \mathrm{g} / \mathrm{L}$ ). County-level land-use and pesticideusage data indicate more crop production in the northern part of the Great Valley than in the southern part, which increases the probability of detecting higher concentrations of atrazine and simazine in the northern part of the Great Valley than in the southern part, where there is more pasture land. Nine out of 10 water samples with simazine concentrations below the MDL were collected in the southern part of the Great Valley Carbonate subunit, whereas 9 out of 14 water samples with simazine concentrations above the 75 th percentile (greater than $0.065 \mu \mathrm{g} / \mathrm{L}$ ) were collected in the northern part.

\section{Small-Scale Similarities and Differences}

Because most pesticides are manufactured compounds that do not occur naturally in the environment, seasonal patterns in the occurrence of pesticide compounds are dependent upon pesticide application. In the Great Valley, concentrations of atrazine were highest in ground water and surface water in May and June (fig. 23).

Typically, higher concentrations of pesticide compounds occur more frequently in surface water than in ground water. Atrazine concentrations in surface-water samples from Muddy Creek (median $=0.11$ $\mu \mathrm{g} / \mathrm{L}$ ) were generally higher than the atrazine concentrations in ground-water samples from the flow-system study (median of all samples $=0.038 \mu \mathrm{g} / \mathrm{L}$ ). An analysis-of-variance test comparing atrazine concentrations in surface-water samples from the Muddy Creek fixed site and atrazine concentrations in ground-water samples from two of the wells from the flow-system study 

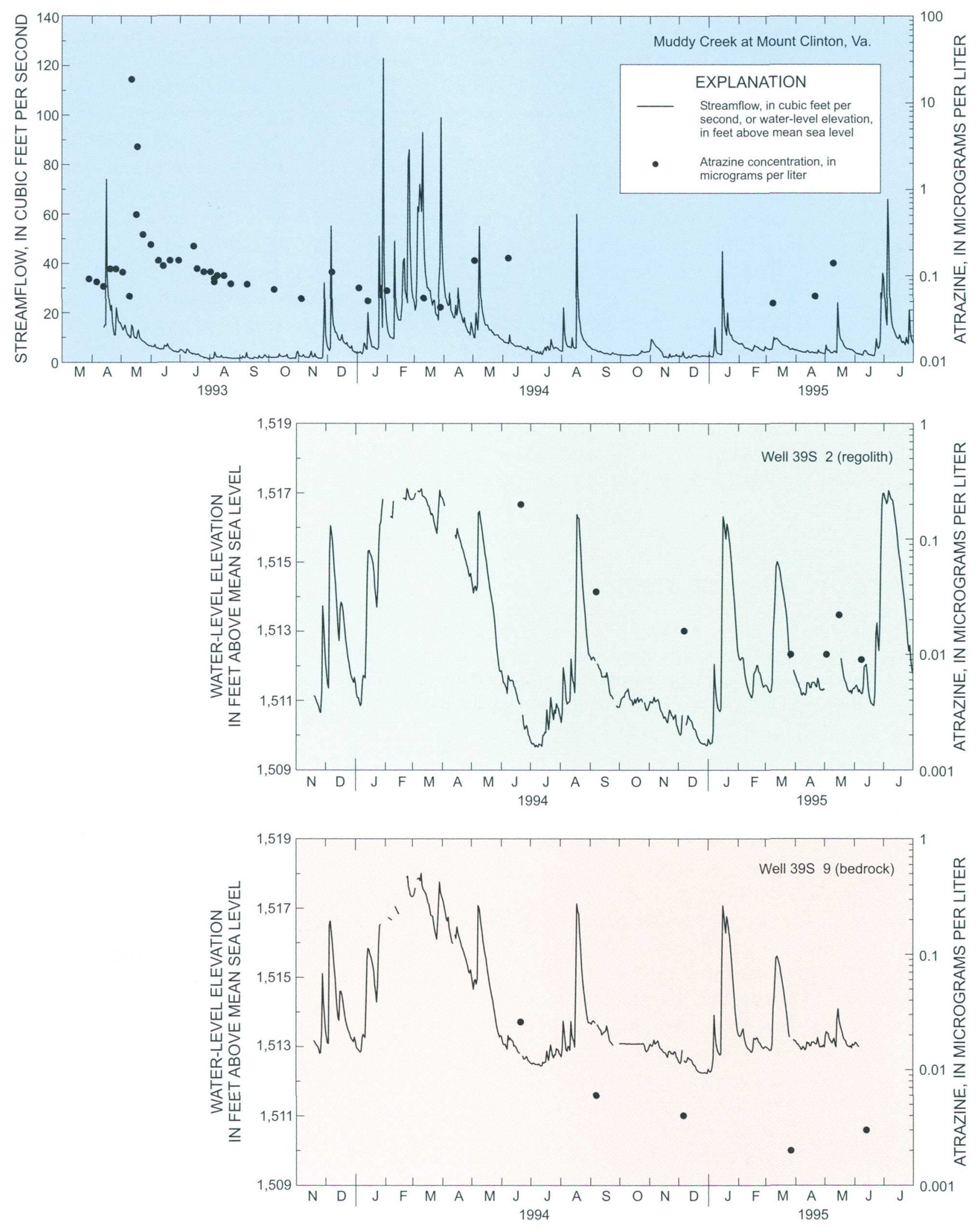

Figure 23. Comparison of streamflow and ground-water-level elevations to atrazine concentrations between the Muddy Creek fixed site and one of the ground-water flow-system well pairs. 
(39S 2 and 39S 9) indicated that at least one of the groups was significantly different from the others $(\mathrm{p}=$ 0.0001 ). A Tukey test indicated that the atrazine concentrations in surface-water samples from the Muddy Creek fixed site were higher than atrazine concentrations in either of the two wells. In addition, for the entire sampling period, the range of atrazine concentrations in surface-water samples $(0.043 \mu \mathrm{g} / \mathrm{L}-18.6 \mu \mathrm{g} / \mathrm{L})$ was higher than the range of concentrations in groundwater samples from either the shallow regolith wells $(0.009 \mu \mathrm{g} / \mathrm{L}-0.20 \mu \mathrm{g} / \mathrm{L})$ or the deeper bedrock wells $(0.002 \mu \mathrm{g} / \mathrm{L}-0.026 \mu \mathrm{g} / \mathrm{L})$.

The hydrographs for all three sites fluctuate in concert, suggesting ground-water and surface-water flow systems are well connected (fig. 23). Because the atrazine concentrations were generally lower in ground-water samples, this suggests that more of the pesticide load in Muddy Creek is supplied from overland runoff, which bypasses the ground-water-flow system.

\section{SUMMARY AND IMPLICATIONS}

Multiple sampling approaches were utilized to assess the occurrence and variability of selected pesticides in ground water and surface water within the Great Valley Carbonate subunit of the Potomac River Basin as part of the National Water-Quality Assessment Program. A smaller, more local water-quality study generally cannot be substituted for a regional study to determine the occurrence and distribution of pesticides in a regional area. Conversely, regional studies cannot be used to determine local water-quality conditions.

Low levels of pesticides are present in ground water and surface water throughout the year in the Great Valley Carbonate subunit of the Potomac River Basin. Out of 47 pesticides and related compounds for which ground-water and surface-water samples from the Great Valley Carbonate subunit were analyzed, 17 were detected in ground-water samples and 24 were detected in surface-water samples. Water-quality criteria for protection of human health and aquatic organisms have not been established for all pesticides and related compounds, and the effects on humans and other animals from long-term exposure to low levels of pesticides are currently unknown. Although most of the water samples collected in subunit-scale studies in the Great Valley Carbonate subunit contained measurable levels of multiple pesticides, none of the measured con- centrations of pesticides for which MCLs for drinking water have been established were above any MCL.

Generally, the most commonly detected pesticides are among the most commonly applied. Atrazine was the most commonly detected pesticide in both ground-water and surface-water samples (it was found in 89 percent of the total number of samples) followed by desethylatrazine (a degradation product of atrazine, found in 88 percent), simazine (found in 79 percent), metolachlor (found in 71 percent), and prometon (found in 40 percent). No other pesticide compound was detected in more than 25 percent of the samples. Degradation products such as desethylatrazine occur frequently in water, but most degradation products were not analyzed. In addition, agricultural use of pesticides is well documented, but the availability of data for non-agricultural uses is limited.

Concentrations of atrazine, desethylatrazine, and simazine in ground-water and surface-water samples are significantly higher in the northern part of the Great Valley (Pennsylvania, Maryland, and West Virginia), which also has a higher percentage of cropland. Concentrations of metolachlor in surface-water samples also demonstrate this geographical distribution, although concentrations of metolachlor in groundwater samples show no significant geographical differences.

Concentrations of atrazine, desethylatrazine, and simazine in ground-water and surface-water samples all show a significant positive correlation to the percentage of cropland: Concentrations of metolachlor did not show a significant correlation to the percentage of cropland. Concentrations of atrazine in both groundwater and surface-water samples also show a significant correlation to the estimated amount of atrazine used in agricultural applications.

Except for prometon, pesticide compounds that commonly occur in samples from the ground-water flow-system study and watershed survey were similar to those that were commonly detected in samples from the subunit survey. The highest concentrations of atrazine were detected consistently in samples from shallow wells completed in regolith (weathered, unconsolidated material covering bedrock) near cropped fields. In pairs of adjacent wells completed in bedrock and regolith, the concentrations of atrazine in samples from the bedrock wells were significantly lower than the concentrations in the regolith wells. Although seasonal and annual variations are evident in pesticide concentrations in samples from individual 
wells, these variations can be distinguished only at very local scales.

Seasonal patterns of pesticide occurrence in surface water show that higher concentrations of atrazine, desethylatrazine, simazine, and metolachlor occur in the spring and low levels of these pesticides occur throughout the year. Other pesticides, such as prometon, whose uses are not necessarily restricted to cropped areas, have peak concentrations at various times of the year. A greater number of pesticides were detected in stream samples from Muddy Creek (19) than were found in stream samples from the Shenandoah River (10). The highest concentrations of atrazine, desethylatrazine, metolachlor, and simazine were detected in samples from Muddy Creek. Occasionally, samples collected during the application period immediately following spring runoff events were found to have concentrations of atrazine or simazine that were above their respective MCLs. Concentrations of atrazine and simazine in a water sample collected five days later were below their respective MCLs. Median concentrations of metolachlor, prometon, and simazine were significantly higher in samples from Shenandoah River, however, and median concentrations of desethylatrazine were significantly higher in samples from Muddy Creek. No significant difference was detected between the median concentrations of atrazine in Muddy Creek and Shenandoah River.

Streamflow in Muddy Creek and ground-water levels from one of the regolith-bedrock well pairs in the flow-system study site fluctuate in concert, indicating the ground-water and surface-water flow systems are well connected. Concentrations of atrazine were significantly higher in surface-water samples from Muddy Creek, however, suggesting that overland runoff contributes more atrazine to the stream than does ground water. 


\section{SELECTED REFERENCES}

Anderson, J.R., Hardy, E.E., Roach, J.T., and Witmer, R.E., 1976, A land use and land cover classification system for use with remote sensor data: U.S. Geological Survey Professional Paper 964, 28 p.

Aspelin, A.L., 1994, Pesticide industry sales and usage, 1992 and 1993 market estimates: U.S. Environmental Protection Agency, Office of Pesticide Programs, Biological and Economic Analysis Division, Economic Analysis Branch Report 733-K-94-001, 33 p.

Barbash, J.E., and Resek, E.A., 1996, Pesticides in ground water - distribution, trends, and governing factors: Chelsea, Michigan, Ann Arbor Press, 588 p.

Briggs, S. A., 1992, Basic guide to pesticides - their characteristics and hazards: Washington, D.C., Taylor \& Francis, p. 10-17.

Denis, J.M., and Blomquist, J.D., 1995, Nitrate in streams in the Great Valley Carbonate subunit of the Potomac River Basin: U.S. Geological Survey Fact Sheet 161-95, 4 p.

Ferrari, M.J., and Ator, S.W., 1995, Nitrate in ground water in the Great Valley Carbonate subunit of the Potomac River Basin: U.S. Geological Survey Water-Resources Investigations Report 95-4099, 6 p.

Gerhart J.M., and Brakebill, J.W., 1996, Design and implementation of a sampling strategy for a water-quality assessment of the Potomac River Basin: U.S. Geological Survey Water-Resources Investigations Report 96-4034, 31 p.

Gianessi, L.P., and Puffer, C.A., 1990 (revised April 1991), Herbicide use in the United States: Washington, D.C., Resources for the Future, Quality of the Environment Division, $128 \mathrm{p}$.

1992a, Fungicide use in U.S. crop production: Washington, D.C., Resources for the Future, November 1992 [variously paged].

1992b, Insecticide use in U.S. crop production: Washington, D.C., Resources for the Future, August 1992 [variously paged].

Gilliom, R.J., Alley, W.M., and Gurtz, M.E., 1995, Design of the National Water-Quality Assessment Program -- Occurrence and distribution of water-quality conditions: U.S. Geological Survey Circular 1112, 33 p.

Goodbred, S.L., Gilliom, R.J., Gross, T.J., Denslow, N.P., Bryant, W.L., and Schoeb, T.R., 1997, Reconnaissance of $17 \beta$-estriadiol, 11-ketotestosterone, vitellogenin, and gonad histopathology in common carp of the United States streams: Potential for contaminant-induced endocrine disruption: U.S. Geological Survey Open-File Report 96-627, $47 \mathrm{p}$.

Helsel, D.R., and Hirsch, R.M., 1992, Statistical methods in water resources: Amsterdam, Elsevier Science Publishers, $522 \mathrm{p}$.

Hitt, K.J., 1994, Refining 1970's land-use data with 1990 population data to indicate new residential development: U.S. Geological Survey Water-Resources Investigations Report 94-4250, 15 p.
Koterba, M.T., Wilde, F.D., and Lapham, W.W., 1995, Groundwater data-collection protocols and procedures for the National Water-Quality Assessment Program: Collection and documentation of water-quality samples and related data: U.S. Geological Survey Open-File Report 95-399, $113 \mathrm{p}$.

Lapham, W.W., Wilde, F.D., and Koterba, M.T., 1997, Guidelines and stand procedures for studies of ground-water quality: Selection, installation, and documentation of wells, and collection of related data: U.S. Geological Survey Water-Resources Investigations Report 96-4233, $110 \mathrm{p}$.

Larșon, S.L., Capel, P.D., and Majewski, M.S., 1997, Pesticides in surface waters - distribution, trends, and governing factors: Chelsea, Michigan, Ann Arbor Press, 373 p.

Leahy, P.P., Rosenshein, J.S., and Knopman, D.S., 1990, Implementation plan for the National Water-Quality Assessment Program: U.S. Geological Survey Open-File Report 90$174,10 \mathrm{p}$.

Maryland Office of State Planning, 1991, Maryland Geographic Information System (MAGI) land use/land cover: Baltimore, Maryland.

Meister Publishing Company, 1997, Farm Chemicals Handbook '97: Willoughby, Ohio, Meister Publishing [variously paged].

Mitchell, W.B., Guptill, S.C., Anderson, K.E., Fegeas, R.G., and Hallam, C.A., 1977, GIRAS -- A geographical information, retrieval, and analysis system for handling land use and land cover data: U.S. Geological Survey Professional Paper 1059, 16 p.

Mueller, D.K., Martin, J.D, and Lopes, T.J., 1997, Quality-control design for surface-water sampling in the National Water-Quality Assessment Program: U.S. Geological Survey Open-File Report 97-223, 17 p.

Pait, A.S., De Souza, A.E., and Farrow, D.R.G., 1992, Agricultural pesticide use in coastal areas--A national summary: Rockville, Maryland, National Oceanic and Atmospheric Administration, Strategic Environmental Assessments Division, Office of Ocean Resources Conservation and Assessment, National Ocean Service, 112 p.

Roeser, L.S., 1988, Pesticide use in the Chesapeake Bay Basin: U.S. Environmental Protection Agency, Chesapeake Bay Liaison Office, CBP/TRS 23/88, 74 p.

Shelton, L.R., 1994, Field guide for collecting and processing stream-water samples for the National Water-Quality Assessment Program: U.S. Geological Survey Open-File Report 94-455, 42 p.

Taylor, J.K., 1987, Quality assurance of chemical measurements: Lewis Publishers, Inc., Chelsea, Michigan, 328 p.

U.S. Department of Commerce, 1995, 1992 Census of Agriculture -- Geographic series 1B: Bureau of the Census, Washington, D.C., CD-92-AG-1B, CD-ROM.

U.S. Environmental Protection Agency, 1989, Health advisory summaries: U.S. Environmental Protection Agency, Office of Water [variously paged]. 
1990, National Pesticide Survey summaries: U.S. Environmental Protection Agency, Office of Water, Office of Pesticides and Toxic Substances [variously paged].

1994, National primary drinking water standards: U.S. Environmental Protection Agency, Office of Water, EPA 810-F-94-001, 2 p.

U.S. Geological Survey, 1996, NAPP and NHAP Photographic Enlargements: U.S. Geological Survey Fact Sheet FS-10196, 1 p.

1997, Pesticides in surface waters--Current understanding of distribution and major influences: U.S. Geological Survey Fact Sheet 039-97, 4 p.

Virginia Department of Conservation and Recreation, Division of Soil and Water Conservation (DCR-DSWC), 1989, Virginia Geographic Information System (VIRGIS) land use/ land cover: Information Support Systems Laboratory, Agricultural Engineering Department, Virginia Polytechnic Institute.

Wershaw, R.L., Fishman, M.J., Grabbe, R.R., and Lowe, L.E., eds., 1987, Methods for the determination of organic substances in water and fluvial sediments: U.S. Geological Survey Techniques of Water-Resources Investigations, book 5, chap. A3, 80 p.

Zaugg, S.D., Sandstrom, M.W., Smith, S.G., and Fehlberg, K.M., 1995, Methods of analysis by the U.S. Geological Survey National Water-Quality Laboratory-- determination of pesticides in water by $\mathrm{C}-18$ solid-phase extraction and capillary-column gas chromatography/mass spectrometry with selected-ion monitoring: U.S. Geological Survey Open-File Report 95-181, 49 p. 


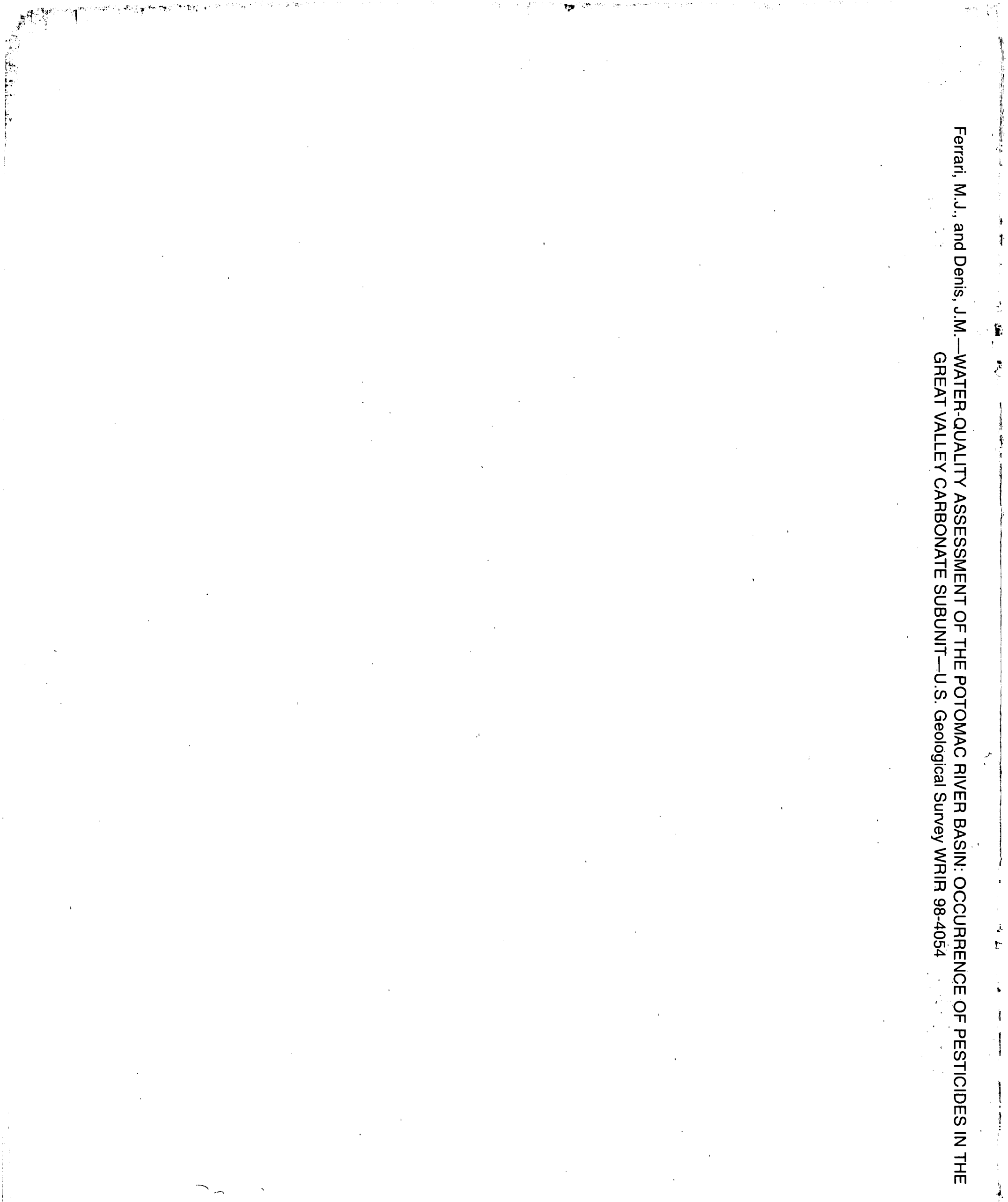

